\title{
O ATIVISMO JUDICIAL NA JUSTIÇA ELEITORAL: ANÁLISE DE CASOS E MECANISMOS DE LEGITIMAÇÃO DEMOCRÁTICA*
}

\author{
Brenda de Quadros Pereira** \\ Carolina Moraes Migliavacca***
}

\section{RESUMO}

0 presente artigo científicoestuda o fenômeno do ativismo judicial na Justiça Eleitoral brasileira, explanando a origem, a estrutura e as funções dessa Justiça especializada e o desenvolvimento da atuação ativista judicial, bem como suas concepções negativas e positivas, conforme doutrina nacional. Aborda as críticas à conduta ativista e, em contraponto, os argumentos que fundamentam sua aplicação, visando promover a democracia participativa e fortalecer a república. Por meio de estudos de casos, demonstra-se que as vicissitudes da Justiça Eleitoral brasileira justificam a atitude proativa dos magistrados. Assim, esse comportamento recebe especial contorno normativo. Ao final, insere-se a proposta dos mecanismos de legitimação democrática, a fim de garantir transparência e pluralidade ao fenômeno.

Palavras-chave:Justiça Eleitoral. Ativismo Judicial. Constituição Federal. Democracia. Função normativa. Mecanismos de legitimação democrática.

* Artigo apresentado ao Curso de Bacharelado em Direito do Centro Universitário Metodista - IPA, como requisito parcial para obtenção do Grau de Bacharel em Direito.

** Graduanda do Curso de Bacharelado em Direito do Centro Universitário Metodista - IPA.

*** Orientadora do artigo, Mestre em Direito - Direito Processual Civil e professora do Curso de Bacharelado em Direito do Centro Universitário Metodista - IPA. 


\section{THE JUDICIAL ACTIVISM IN ELECTORAL JUSTICE: CASE ANALYSE AND MECHANISMS OF DEMOCRATIC LEGITIMACY}

\section{ABSTRACT}

This article studies the phenomenon of judicial activism in the Brazilian Electoral Justice, explaining the origin, structure and functions of this specialized Justice and the development of judicial activist activity, as well as its negative and positive conceptions, according to national doctrine. Criticisms of activist conduct and, in counterpoint, the arguments that support its application, with a view to promoting participatory democracy and strengthening the republic. Through case studies demonstrates the many variations of the Brazilian Electoral Justice justify the proactive attitude of the judges. Thus, this behavior receives a special normative outline. At the end, it inserts the proposal of the mechanisms of democratic legitimation, in order to guarantee transparency and plurality to the phenomenon.

Key words:Electoral Justice. Judicial Activism. Constitution. Democracy. Normative Function. Mechanisms of Democratic legitimation.

\section{INTRODUÇÃO}

0 presente trabalho visa a estudar a importância do ativismo judicial na Justiça Eleitoral, para tanto, inicialmente, apresenta a origem e estrutura dessa Justiça especializada no Brasil, tendo em vista os processos políticos que circundaram seu desenvolvimento. Além disso, demonstrar-se-á as funções típicas e atípicas do Poder Judiciário eleitoral, que instrumentalizam a promoção da democracia participativa e representativa.

Para mais, a partir da exposição do desenvolvimento, da organização e das funções da Justiça Eleitoral, será incorporado um olhar crítico sobre as bases desse ramo, a fim de exteriorizar suas vicissitudes e debilidades, que clamam por um olhar atento e preocupado do operador do direito e da sociedade em si, haja vista o tratamento negligente despendido pelo Poder Legislativo.

Nesse passo, considerando que é imprescindível à função típica julgadora a utilização de técnicas de interpretação, propõe- 
-se estabelecer que a intensificação da criatividade do Judiciário está relacionada com a outorga de maior liberdade de atuação a esse Poder, que, por via de consequência, introduziu o fenômeno da judicialização e, em seguida, o ativismo judicial.

Ambos os fenômenos guardam relação com a omissão dos Poderes Legislativo e Executivo no que tange suas funções. Assim, diante desse quadro, pretendem suprir as negligências estatais a fim de promover direitos fundamentais. À vista disso, serão estabelecidas distinções entre a judicialização e o ativismo, objetivando compreender a extensão do fenômeno ativista.

A partir de então, presta-se uma análise do ativismo judicial e do risco de lesão à separação de poderes, construindo um caminho capaz de conciliar as duas teorias. Afora isso, serão concebidos os limites ao ativismo judicial e suas concepções negativas e positivas, segundo a doutrina brasileira.

Ato contínuo, tratar-se-á das omissões legislativas em matéria eleitoral, concluindo que há, de fato, atuação ativista do Judiciário que visa sanar lacunas. Nessa oportunidade, será discorrido sobre os diversos tipos de decisões ativistas, sendo constatado que há observância à democracia, tanto em atos representativos quanto contramajoritários, quando a atuação se dá seguindo os preceitos constitucionais.

Em relação à Justiça Eleitoral, far-se-á análise de certos casos, julgados pelo Tribunal Superior Eleitoral e o Supremo Tribunal Federal, para demonstrar ao leitor a presença e necessária intervenção judicial na atividade legislativa típica. Em seguimento, o escopo proposto é de esclarecer a transição do poder regulamentar para normativo, como também as críticas e os atributos dessa transformação, trazendo a prevalência dos direitos fundamentais, da cidadania e da república.

Finalmente, com o intento que garantir segurança jurídica, participação popular e pluralismo para as decisões ativistas, serão sugeridos mecanismos de legitimação democrática, como o 
instituto do amicus curiae e das audiências públicas.Esses instrumentos propiciarão a atuação da sociedade aberta e reconhecerão a força dos fatores reais de poder, estando na figura do cidadão o papel de maior destaque.

\section{A JUSTIÇA ELEITORAL BRASILEIRA}

A Justiça Eleitoral brasileira está organizada nos moldesdo artigo 118 e seguintes da Constituição Federal de 1988, e, atualmente, compõe a estrutura do Poder Judiciário, atuando como instituição permanente e em funcionamento continuado ${ }^{1}$.

Esse ramo especializado cuida das relações jurídicas atinentes ao Direito Eleitoral, tutelando e promovendo a mais ampla democracia participativa e representativa, fundamentoda República brasileira, de acordo com o artigo $1^{\circ}$, V, da Constituição Federal de 1988, e cláusula pétrea, pelo artigo 60, §4º , II, do mesmo diploma. Nessa esteira, englobam os fundamentos da Justiça Eleitoral os conceitos de soberania, democracia, participação popular, voto, sufrágio, mandato e representação ${ }^{2}$.

Não obstante, interessa destacar que a estrutura e as funções da Justiça Eleitoral contemporânea são o resultado de um processo de evolução da política nacional, cujo estudo,que se apresenta aseguir, será de suma importância para compreender seus avanços e debilidades.

\subsection{A ORIGEM E A ESTRUTURA DO PODER JUDICIÁRIO ELEITORAL}

A Justiça Eleitoral, como atribuição do Poder Judiciário, no Brasil, foi criada pelo Código Eleitoral de 1932 e ratificada pela Constituição Federal de 1934, sendo a ela atribuído o serviço de

1 RIBEIRO, Fávila. Pressupostos constitucionais do direito eleitoral: no caminho da sociedade participativa. Porto Alegre: Sergio Antonio Fabris Editor, 1990. p. 107.

2 ZILIO, Rodrigo López. Direito eleitoral. ed. 5. Porto Alegre: Verbo Jurídico, 2016. p. 19-20. 
promover a democracia representativa e participativa ${ }^{3}$. Todavia, as atividades eleitoralistas,com vistas às eleições de membros do Legislativo, tiveram início logo após a declaração de independência do Brasil, notadamente com o Decreto de 26 de março de $1824^{4}$.

Durante quase um século, as funções eleitorais eram atribuições do Poder Legislativo. Com isso, o sistema eleitoral enfrentava diversas fraudes e violências que anulavam a vontade popular, dentre elas o voto de cabresto e a degola ${ }^{5}$. Nesse quadro, a insegurança na área eleitoral conjugada com a instabilidade política da época enfraqueciam o Estado e desmotivavam os estudos sobre a matéria, o que impedia seu desenvolvimento científico ${ }^{6}$.

Até então,a legislação eleitoral era formada por decretos e leis, que progressivamente alteravamo sistema de realização do pleito e a capacidade para exercício do sufrágio. A primeira codificação eleitoralista nasce somente em 1932, como resultado das reivindicações da revolução constitucionalista de São Paulo, instituindoo voto direto, obrigatório e secreto, além de entregar ao Poder Judiciário a incumbência de organizar oprocesso eleitoral, a fim de afastar as irregularidades praticadas, criando a Justiça Eleitoral, conforme anteriormente referido ${ }^{7}$.

3 CASTRO, Edson de Resende. Teoria e prática do direito eleitoral. ed. 4, rev. atual. Belo Horizonte: Mandamentos, 2008. p. 45.

4 JOBIM, Nelson et al. Legislação eleitoral no Brasil: do século XVI a nossos dias. Brasília: Senado Federal, Subsecretaria de Biblioteca, 1996. p. 43.

5 Degola era a atribuição que a Comissão de Verificação do Poder Legislativo possuía para barrar a posse de um candidato eleito por entender que durante o pleito houve algum erro. Geralmente, utilizavam para barrar a diplomação de um candidato que não atendia as vontades do grupo político dominante da época. (VOTAÇÃO na república velha tinha fraude sofisticada. Estadão, São Paulo, n. p, 30 out. 2010. Disponível em: <https://brasil. estadao.com.br/noticias/geral,votacao-na-republica-velha-tinha-fraudesofisticada-imp-,632063> Acesso em: 02 set. 2018).

6 CASTRO, Edson de Resende. Teoria e prática do direito eleitoral. ed. 4, rev. atual. Belo Horizonte: Mandamentos, 2008. p. 36.

7 ITAGIBA, Ivanir Nogueira. 0 Direito Eleitoral na atualidade. In: MEDEIROS, Renata Leite Motta Paes (Coord.). Estudos Eleitorais, v. 12, n. 2, p. 137-150 Mai/Ago, 2017. p. 144. 
Ato contínuo, editou-se o Código Eleitoral de 1935, que concedeu o direito de exercício do sufrágio às mulheres e regulamentou as atribuições do Ministério Público na Justiça Eleitoral. No entanto, com o golpe de Estado instaurado por Getúlio Vargas, conhecido por Estado Novo, a Justiça Eleitoral e os direitos democráticos alcançados foram extintos pela Constituição Federal de $1937^{\circ}$. Com a redemocratização do país, em 1945, publicou-se a Lei Constitucional no 9, que recriou a Justiça Eleitoral, seguida pelo Decreto-Lei $\mathrm{n}^{\circ} 7.586$, que regulava o alistamento eleitoral e as eleições, e pelo Código Eleitoral de $1950^{9}$.

O diploma eleitoralista de 1950 perdeu vigência com a entrada em vigor do Código Eleitoralde 1965, que regulamenta as relação eleitorais e partidárias até o presente. Cumpre ressaltar queo referido diploma infraconstitucional, por ser concebido no início do regime militar,carrega"a marcado autoritarismo, às vezes com regras incompatíveis com o Estado Democrático de Direito hoje vivido entre nós"10, adverte Castro.

Além disso, em que pese a Constituição Federal de 1988tenha nascido para iluminar o país com a adoção do regime político democrático, reservou a uma lei complementarfutura as disposições sobre a organização e a competência dos tribunais, dos juízes e das juntas eleitorais, nos termos do seu artigo 121, sem maiores cuidados com a estrutura da Justiça Eleitoral.Assim, enquanto não editada a referida lei, o Código Eleitoral de 1965 restou recepcionado como lei complementar nas normas que

8 FICO, Carlos. História do Brasil contemporâneo: da morte de Vargas aos dias atuais. São Paulo: Editora Contexto, 2015. p. 14.

9 ITAGIBA, Ivanir Nogueira. O Direito Eleitoral na atualidade. In: MEDEIROS, Renata Leite Motta Paes (Coord.). Estudos Eleitorais, v. 12, n. 2, Mai/ Ago. p. 137-150, 2017. p. 144-145.

10 CASTRO, Edson de Resende. Teoria e prática do direito eleitoral. ed. 4, rev. atual. Belo Horizonte: Mandamentos, 2008. p. 34. 
tratam sobre organização e competências e como lei ordinária nas demais ${ }^{11}$.

Dessa forma, a Justiça Eleitoral estrutura-se, atualmente, pelo Tribunal Superior Eleitoral, composto de sete ministros, no mínimo, quetem jurisdição nacional sob a matéria eleitoral, sendo submetido apenas ao Supremo Tribunal Federal, nas questões constitucionais, epelos Tribunais Regionais Eleitorais, distribuídos nos Estados-membros, formados, em cada Estado, por um pleno de sete desembargadores.Ainda, possuijuízes Eleitorais, que atuam na jurisdição de zonas eleitorais. Finalmente, as Juntas Eleitorais, que são constituídas pelos JuízesEleitorais e dois ou quatro cidadãos da comunidade local, compõem a estrutura desta Justiça especializada ${ }^{12}$.

Compete ressaltar que a Justiça Eleitoral não possui estrutura própria, isto é, os ministros do seu órgão superior são oriundos do Supremo Tribunal Federal e do Superior Tribunal de Justiça, além de dois advogados escolhidos em lista sêxtupla; os desembargadores e juízes de primeiro grau, no mesmo sentido, advêm dos Tribunais de Justiça ou dos Tribunais Regionais Federais, bem como há dois advogados indicados ${ }^{13}$. Ademais, interessa esclarecer que inexistevitaliciedade aos magistrados, pois estão sujeitos a peculiar forma de recrutamento com base na periodicidade e

11 TRIBUNAL SUPERIOR ELEITORAL. Código Eleitoral Anotado e Legislação Complementar. [S.l., S.n., S.d.]. Disponível em: <http://www.tse.jus.br/legislacao/codigo-eleitoral/codigo-eleitoral-1/codigo-eleitoral-lei-nb0-4.737de-15-de-julho-de-1965\#5-tit3-cap4>. Acesso em: 02 set. 2018.

12 MICHELS, Vera Maria Nunes. Direito eleitoral: de acordo com a Constituição Federal, LC 64/90, Leis 9.096/95, 9.504/97, 11.300/06, EC 52/06 e Resoluções do TSE. Porto Alegre: Livraria do Advogado, 2006. p. 47.

13 ZILIO, Rodrigo López. Direito eleitoral. ed. 5. Porto Alegre: Verbo Jurídico, 2016. p. 43-45. 
na alternância ${ }^{14}$. Afora isso, o Ministério Público Eleitoral existe somente como uma atribuição do Ministério Público da União ${ }^{15}$.

Diante da ausência de estrutura autônoma e de imposição constitucional que determine a edição dalei complementarsob as bases da democracia, a organização e as funções da Justiça Eleitoral ficam à mercê das regulamentações do Código Eleitoral de 1965 e das parcas normas ordinárias editadas após a nova ordem constitucional, notadamente, a Lei das Eleições (Lei n. 9.504/1997) e a Lei dos Partidos Políticos (Lei n. 9.096/1995). Ocorre que, os mencionados regramentos são insuficientes para compreender os institutos do Direito Eleitoral, inviabilizando a efetivaçãoda mais ampla, transparente e participativa democracia ${ }^{16}$.

Outrossim, deve se mencionar que a Justiça Eleitoral integra o Poder Judiciário federal, conforme dispõe o artigo 92, V, da Constituição Federal de 1988. A matriz federal concretiza-se pela necessária edição de normas uniformes, cuja aplicabilidade deve atingir todo território nacional, tendo em vista que esse ramo especial resguarda a democracia e o Estado Democrático de Direito, o que ultrapassa interesses meramente estaduais ${ }^{17}$.

Sendo assim, observe-se que, embora enfrente problemas estruturais, muitos oriundos de seu conturbado desenvolvimento histórico,a Justiça Eleitoral possui a nobre e fundamental

14 RIBEIRO, Fávila. Pressupostos constitucionais do direito eleitoral: no caminho da sociedade participativa. Porto Alegre: Sergio Antonio Fabris Editor, 1990. p. 108.

15 ZILIO, Rodrigo López. Direito eleitoral. ed. 5. Porto Alegre: Verbo Jurídico, 2016. p. 54.

16 MACEDO, Elaine Harzheim. A função normativa da Justiça Eleitoral brasileira no quadro da separação dos poderes. Revista do Instituto do Direito Brasileiro, p.13871-13884, 2013. Disponível em: <http://cidp.pt/publicacoes/ revistas/ridb/2013/12/2013_12_13871_13884.pdf> Acesso em: 25 set. 2018. p. 13874.

17 SOBRAL, Daniel Santos Rocha. A Justiça Eleitoral e a magistratura federal. In: MACHADO, José Amilcar (Coord.). Jornada de Direito Eleitoral das Escolas de Magistratura Federal, v. 20. Brasília: Tribunal Regional Federal da 1a Região, ESMAF, p. 73-88, jun. 2013. p. 75. 
finalidade de promover a participação popular, desenvolvendo a democracia e efetivando o Estado Democrático de Direito. Portanto, a atuação nesse ramo especializado deve se basear com muito mais afinco nas suas finalidades democráticas do que na estrutura essencialmente legislativa vigente.

\subsection{AS FUNÇÕES TÍPICAS E ATÍPICAS DA JUSTIÇA ELEITORAL}

Os Poderes da União exercem funções típicas, que são as suas competênciaspreponderantesatribuídas constitucionalmente, e atípicas, que compreendem as atividades principais dos demais ${ }^{18}$. A Justiça Eleitoral, por pertencer ao Poder Judiciário, exerce tipicamente a função jurisdicional, e, de modo atípico, a atividade legiferante, quando edita normas para seu pessoal, por exemplo, como também a executiva, nos casos de administrar suas questões internas.

Contudo, aJustiça Eleitoral possui outras funções, igualmente preponderantes, que objetivam viabilizara busca pela efetivação de seusfins maiores, quais sejam, resguarda da democracia e promoção do Estado Democrático de Direito, visando a superar, em certa medida, a inexistência de estrutura própria e de legislação adequada à realidade política atual. Desse modo, além da função jurisdicional, exerce função administrativa, consultiva e regulamentar ${ }^{19}$, as quais merecem breves comentários.

Envolve a atividade julgadora da Justiça Eleitoral a resolução de conflitos na esfera especializada, por meio do processamento e julgamento de ações eleitorais cíveis e criminais ${ }^{20}$, também

18 ROSA, Antonio José Miguel Feu. Direito constitucional. São Paulo: Saraiva, 1998. p. 209.

19 ZILIO, Rodrigo López. Direito eleitoral. ed. 5. Porto Alegre: Verbo Jurídico, 2016. p. 49.

20 SOBRAL, Daniel Santos Rocha. A Justiça Eleitoral e a magistratura federal. In: MACHADO, José Amilcar (Coord.). Jornada de Direito Eleitoral das Escolas de Magistratura Federal, v. 20. Brasília: Tribunal Regional Federal da 1a Região, ESMAF, p. 73-88, jun. 2013. p. 75. 
denominadas de processo eleitoral stricto sensu ${ }^{21}$. Trata-se, em outras palavras, da típica atuação jurisdicional que objetiva dirimir conflitos de interesse.

Por outro lado, a função administrativa da Justiça Eleitoral impõe uma atuação diferenciada em relação aos demais órgãos do Poder Judiciário, visto que o administrador não pode ser inerte, já que compete a ele a administração do sistema eleitoral, ou seja, de todos os procedimentos que envolvem o alistamento eleitoral e a organização do pleito até a diplomação $0^{22}$.

Outra particularidade do Poder Judiciário eleitoral é a função consultivaprevista nos artigos 23, XII, e 30, VIII, do Código Eleitoral. Essa atribuição é conferida ao Tribunal Superior Eleitoral e aos Tribunais Regionais Eleitorais, e pode ser solicitada por autoridade pública ou partido político. Cumpre frisar que a consulta não pode versar sobre caso concreto, uma vez que ocasionaria a antecipação da resolução do conflito. Não obstante, esse instrumento torna-se necessário e interessante por auxiliar candidatos e partidos políticos a evitarem práticas que contrariem o entendimento da Justiça Eleitoral ${ }^{23}$.

Já a atividade regulamentar,segundo Zilio, é substanciada no poder regulamentador inerente a todo e qualquer órgão judicial ${ }^{24}$.Castro, por sua vez, defende que a referida atribuição se singulariza na Justiça Eleitoral ao compreender a possibilidade do Tribunal Superior Eleitoral editar instruções necessárias para normatizar o sistema e o processo eleitoral, nos termosdo artigo 23, IX, do Código Eleitoral edo artigo 105 da Lei n. 9.504/9725.

21 ZILIO, Rodrigo López. Direito eleitoral. ed. 5. Porto Alegre: Verbo Jurídico, 2016. p. 289.

22 CASTRO, Edson de Resende. Teoria e prática do direito eleitoral. ed. 4, rev. atual. Belo Horizonte: Mandamentos, 2008. p. 47-48.

23 CASTRO, Edson de Resende. Teoria e prática do direito eleitoral. ed. 4, rev. atual. Belo Horizonte: Mandamentos, 2008. p. 61.

24 ZILIO, Rodrigo López. Direito eleitoral. ed. 5. Porto Alegre: Verbo Jurídico, 2016. p. 49.

25 CASTRO, Edson de Resende. Teoria e prática do direito eleitoral. ed. 4, rev. atual. Belo Horizonte: Mandamentos, 2008. p. 62. 
Sobre o poder regulamentador na Justiça Eleitoral, Macedo vai mais longe ao reconhecer a utilização dessa função para além de simples instruções e organizações internas, passando, efetivamente, a criar direitos, tendo em vista casos de inércia legislativa.Acrescentou, ainda, que o refúgio e solução para os vácuos legislativos tem sido a atuação do Poder Judiciário, dado que, para a referida autora, "espaço não ocupado, é espaço que se ocupa!"26.

Ante o exposto, depreende-se quea Justiça Eleitoral possui um leque significativo de funções típicas e atípicas, que propiciam a busca pelo cumprimento de suas finalidades democráticas. Assim, é possível conceber que essas funções, por atuarem de forma teleológica, podem se libertar das limitações legislativas e servirem como instrumento imediato para minimizar as debilidadesda Justiça Eleitoral.

\section{ATIVISMO JUDICIAL}

Para Schapp, o juiz parte seu trabalho do caso que lhe foi exposto, procurando, logo após, a determinação legal que seja aplicável ${ }^{27}$, no campo da sua função típica julgadora. A incidência da norma correta depende da utilização de técnicas de interpretação, que possuem critérios capazes de promover a mais correta aplicação da lei no caso em questão ${ }^{28}$.

0 ativismo judicial nasce justamente da atividade interpretativa dos juízes, quando ultrapassam os limites da lei, ou, até

26 MACEDO, Elaine Harzheim. A função normativa da Justiça Eleitoral brasileira no quadro da separação dos poderes. Revista do Instituto do Direito Brasileiro, Ano 2, no 12, p.13871-13884, 2013. Disponível em: <http:// cidp.pt/publicacoes/revistas/ridb/2013/12/2013_12_13871_13884.pdf> Acesso em: 25 set. 2018. p. 13874.

27 SCHAPP, Jan. Problemas fundamentais da metodologia jurídica. Trad. por Ernildo Stein. Porto Alegre: Sergio Antonio Fabris Editor, 1985. p. 81.

28 BARROSO, Luís Roberto. Interpretação e aplicação da Constituição: fundamentos de uma dogmática constitucional transformadora. São Paulo: Saraiva, 2009. p. 9. 
mesmo, inovam o ordenamento jurídico, frente a casos de inadequação ou omissão legislativa. Impende ressaltar, todavia, que o desenvolvimento dessa conduta proativa não se opera de forma tão simples, uma vez que compreende a ampliação da atuação do Poder Judiciário e o risco de lesão à separação de poderes ${ }^{29}$.

Assim, pretende-se, nas páginas a seguir, discorrer acerca do desenvolvimento do ativismo judicial e demonstrar de que forma o comportamento proativo se configura no Brasil, apresentando suas faces negativas e positivas, com basena doutrina nacional.

\subsection{O DESENVOLVIMENTO DO FENÔMENO ativismoJUDICIAL}

A interpretação é essencial para o exercício da típica função julgadora do Poder Judiciário e, pelos ensinamentos de Eros Grau, possui caráter constitutivo, não meramente declaratório, pois a aplicação da lei opera a inserção do direito na realidade ${ }^{30}$. Afora isso, ao julgador também é atribuído certo grau de criatividade na sua interpretação, para viabilizar a busca pela resolução de ambiguidades e incertezas que até as leis mais claras podem conter ${ }^{31}$.

A intensificação da criatividade da função jurisdicionalrepresenta a declínio do formalismo jurídico, que reconhecia o juiz apenas como um reprodutor da ordem legal, ou seja, a bocada-lei ${ }^{32}$. Esse movimento aflorou, notadamente, após a Segunda Guerra Mundial, com a promoção de direitos pelas declarações universais e a consolidação do Estado constitucional de direito-

29 CITTADINO, Gisele. Poder Judiciário, ativismo judicial e democracia. Revista da Faculdade de Direito de Campos, v. 2/3, n. 2/3, p. 135-144, 2001-2002. Disponível em: <http://bdjur.stj.jus.br/dspace/handle/2011/25512>. Acesso em: 13 out. 2018. p. 137-138.

30 GRAU, Eros Roberto. Por que tenho medo dos juízes (a interpretação/ aplicação do direito e os princípios), ed. 6. São Paulo: Malheiros Editores LTDA, 2013. p. 20.

31 CAPPELLETTI, Mauro. Juízes legisladores? trad. por Carlos Alberto Álvaro de Oliveira. Porto Alegre: Sergio Antonio Fabris Editor, 1993. p. 21.

32 CAPPELLETTI, Mauro. Juízes legisladores? trad. por Carlos Alberto Álvaro de Oliveira. Porto Alegre: Sergio Antonio Fabris Editor, 1993. p. 31. 
em prejuízo ao modelo do Estado legislativo de direito até então vigente ${ }^{33}$.

Em decorrência, ao intérprete-julgador foi conferida maior liberdade de atuação, para fins de cumprir os preceitos constitucionais. Com essa abertura, há o desenvolvimento de interpretações construtivistas, falando-se, inclusive, da criação de um direito judicial $^{34}$.Nesse passo, relevantes questões sociais e políticas são levadas para apreciação do Poder Judiciário, implementando em diversos países o que a doutrina denomina de judicialização ${ }^{3536} .0$ Poder Judiciário passa, então, a efetivar direitos que cabiam ao Legislativo prever e efetivar esses direitos no plano social, suprindo as faltas de serviço da Administração Pública ${ }^{37}$.

0 fenômeno ativista demonstra suas primeiras faces justamente nesse período de ascensão institucional do Judiciário. Inicialmente, na Suprema Corte americana, possuía natureza conservadora,

33 BARROSO, Luís Roberto. Constituição, democracia e supremacia judicial: direito e política no Brasil contemporâneo. Revista Jurídica da Presidência, v. 12, n. 96, p. 05-43, 2010. p. 07-08.

34 CITTADINO, Gisele. Poder Judiciário, ativismo judicial e democracia. Revista da Faculdade de Direito de Campos, v. 2/3, n. 2/3, p. 135-144, 2001-2002. Disponível em: <http://bdjur.stj.jus.br/dspace/handle/2011/25512>. Acesso em: 13 out. 2018. p. 135.

35 BARROSO, Luís Roberto. Curso de direito constitucional contemporâneo. ed. 4. São Paulo: Editora Saraiva, 2013. p. 410.

36 Alguns autores, como Santos, concebem o fenômeno como a judicialização da política, pois ocorreria sempre que os órgãos jurisdicionais, atuando na sua função típica, afetam as condições da ação política. (SANTOS, Boaventura de Souza. Para uma Revolução Democrática da Justiça. São Paulo: Cortez Editora, 2007, p. 17.). Porém, a fim de facilitar a compreensão, adotar-se-á apenas o termo 'judicialização', nomenclatura única utilizada por Barroso. (BARROSO, Luís Roberto. Judicialização, Ativismo Judicial e Legitimidade Democrática. (Syn)Thesis. vol. 5, n. 1. Rio de Janeiro: Centro de Ciências Sociais da Universidade do Estado do Rio de Janeiro, p. 23-32, 2012. Disponível em: <http://www.e-publicacoes.uerj.br/index.php/synthesis/article/ view/7433/5388>. Acesso em: 20 out. 2018).

37 MARIA PORTO LIMA, Sídia. 0 ativismo judicial e o judiciário eleitoral: um estudo da atividade legislativa do Tribunal Superior Eleitoral. Recife: Universidade Federal de Pernambuco. 2011. p. 23. 
no sentido de garantir adequação com os costumes da época ${ }^{38}$. Contudo, logo passou a ser o mecanismo capaz de instigar uma participação mais intensa do Judiciário, com o fito de promover a concretização das finalidades constitucionais e intervir na atuação dos outros dois Poderes, sem necessariamente pressupor confronto, mas apenas ocupando espaços vazios ${ }^{39}$. Independentemente da natureza, para Branco, o ativismo é utilizado para apontar um exercício arrojado da jurisdição, fora do usual, sobretudo no que tange às opções morais e políticas dos magistrados ${ }^{40}$.

Oberço do ativismo judicial, portanto, é o direito norte-americano, cujo sistema de common law atribui especial importância à jurisprudência dos tribunais. 0 termo judicial activism nasce de um artigo escrito por Arthur Schlesinger Jr., jurista norte-americano, em 1947, que caracterizou o fenômeno ativista como um contraponto à teoria da autocontenção judicial ${ }^{41}$. Nesse trabalho, o referido autor estabelece uma relação entre os membros da Suprema Corte e suas decisões, rotulando-as como ativistas, ou passivistas ${ }^{42}$.

38 BARROSO, Luís Roberto. Judicialização, Ativismo Judicial e Legitimidade Democrática. (Syn)Thesis. vol. 5, n. 1. Rio de Janeiro: Centro de Ciências Sociais da Universidade do Estado do Rio de Janeiro, p. 23-32, 2012. Disponível em: <http://www.e-publicacoes.uerj.br/index.php/synthesis/article/ view/7433/5388>. Acesso em: 14 out. 2018. p. 26.

39 BARROSO, Luís Roberto. Constituição, democracia e supremacia judicial: direito e política no Brasil contemporâneo. Revista Jurídica da Presidência, v. 12, n. 96, p. 05-43, 2010. p. 11.

40 BRANCO, Paulo Gustavo Gonet. Em busca de um conceito fugidio - o ativismo judicial. As novas faces do ativismo judicial. Salvador: Juspodivm, p. 387-401, 2011. p. 392.

41 Autocontenção judicial é a conduta pela qual o Judiciário procura reduzir sua interferência nas ações de outros Poderes. O Brasil abandonou a predominância dessa teoria com a promulgação da Constituição Federal de 1988. (BARROSO, Luís Roberto. Judicialização, Ativismo Judicial e Legitimidade Democrática. (Syn)Thesis. vol. 5, n. 1. Rio de Janeiro: Centro de Ciências Sociais da Universidade do Estado do Rio de Janeiro, p. 23-32, 2012. Disponível em: <http://www.e-publicacoes.uerj.br/index.php/synthesis/article/ view/7433/5388>. Acesso em: 14 out. 2018. p. 26.).

42 BRANCO, Paulo Gustavo Gonet. Em busca de um conceito fugidio - o ativismo judicial. As novas faces do ativismo judicial. Salvador: Juspodivm, p. 387-401, 2011. p. 389. 
Somente para fins de curiosidade, cumpre relatar que, durante anos, a teoria constitucional norte-americana esteve segmentada entre liberais, ou progressistas, favoráveis ao judicial review e ao ativismo judicial, e conservadores, defensores da autocontenção judicial. Atualmente, no entanto, predomina o pensamento progressista, que observa o constitucionalismo democrático ${ }^{43}$.

Em prosseguimento, nota-se, em consonância ao já apresentado, que os fenômenos da judicialização e do ativismo judicial convivem. Conquanto, embora próximos, a judicialização e o ativismo judicial são distintos, uma vez que o primeiro, de acordo Barroso, é um fato que decorre da adoção do regime de governo democrático, do processo de constitucionalização e do sistema de controle de constitucionalidade. Já o segundo é uma escolha sobre o modo proativo de interpretar a Constituição, expandindo e efetivando seus preceitos ${ }^{44}$. Em outras palavras, a judicialização está relacionada com o modelo constitucional vigente, enquanto o ativismo é um comportamento judicial que extrapola os limites da função julgadora, sob a justificação da necessária efetivação dos postulados constitucionais.

Impende esclarecer que tanto a judicialização quanto o ativismo são reflexos do destaque que o Poder Judiciário recebeu nos últimos anos. Observa-se que essa ampliação de atuação judicial, em certa medida, pode, de fato, representar um enfraquecimento do sistema de separação de poderes proposto por Montesquieu e adotado por diversos países ${ }^{45}$.

43 BARROSO, Luís Roberto. Curso de direito constitucional contemporâneo. ed. 4. São Paulo: Editora Saraiva, 2013. p. 416.

44 BARROSO, Luís Roberto. Judicialização, Ativismo Judicial e Legitimidade Democrática. (Syn)Thesis. vol. 5, n. 1. Rio de Janeiro: Centro de Ciências Sociais da Universidade do Estado do Rio de Janeiro, p. 23-32, 2012. Disponível em: <http://www.e-publicacoes.uerj.br/index.php/synthesis/article/ view/7433/5388>. Acesso em: 14 out. 2018. p. 25.

45 MARIA PORTO LIMA, Sídia. 0 ativismo judicial e o judiciário eleitoral: um estudo da atividade legislativa do Tribunal Superior Eleitoral. Recife: Universidade Federal de Pernambuco. 2011. p. 30. 
Nos termosda teoria pura da tripartição de poderes, concerne ao Legislativo editar leis, corrigi-las ou ab-roga-las, ao Executivo fazer paz ou guerra (inclui-se atribuições de Chefe de Estado e Governo no caso do Brasil) e ao Judiciário punir crimes, ou julgar demandas dos particulares. Trata-se de um esquema de distribuição de competências que busca equilibrar as funções do Estado e afastar a tirania ${ }^{46}$.

Diante disso, a judicialização e o ativismo judicial são, em verdade, inconcebíveis com uma distribuição de competência rígida, pois necessitam da abertura da atuação do Judiciário para existirem e demonstrarem sua relevância política na efetivação de direitos fundamentais ${ }^{47}$. Por conseguinte, o que se mostra cabível é uma separação de poderes menos rigorosa, que,em que pesepreserve a estrutura tripartite, permite um controle entre os Poderes, mantendo a independência e garantindo a harmonia entre as funções ${ }^{48}$. Para além, Facchini indica que uma adequada concepção da doutrina de separação de poderes impõe ao Judiciário uma responsabilidade positiva de desempenhar sua função de forma eficiente ${ }^{49}$.

Com efeito, cabe repensar a teoria da separação de poderes sob a perspectiva do Estado de Direito, haja vista queo rígidoconceito puro de Montesquieu era compatível tão somente com a experiência absolutista, inexistente na conjuntura nacional atual. Assim, o dogma da separação de poderes, assumindo forma de sistema

46 MONTESQUIEU, Charles de Secondat. Baron de. 0 espírito das leis. ed. 7. Trad. por Pedro Vieira Mota. São Paulo: Saraiva, 2000. p. 166-167.

47 FACCHINI NETO, Eugênio. O judiciário no contexto do poder: uma abordagem de direito comparado. Revista Ajuris, v. 37, n. 118, junho/2010. Disponível em: <https://bdjur.tjdft.jus.br/xmlui/handle/123456789/8569>. Acesso em: 16 out. 2018. p. 6.

48 MARIA PORTO LIMA, Sídia. 0 ativismo judicial e o judiciário eleitoral: um estudo da atividade legislativa do Tribunal Superior Eleitoral. Recife: Universidade Federal de Pernambuco, 2011. p. 28.

49 FACCHINI NETO, Eugênio. O judiciário no contexto do poder: uma abordagem de direito comparado. Revista Ajuris, v. 37, n. 118, junho/2010. Disponível em: <https://bdjur.tjdft.jus.br/xmlui/handle/123456789/8569>. Acesso em: 16 out. 2018. p. 9. 
de freios e contrapesos, deve atender às exigências da sociedade aberta dos intérpretes da Constituição e se adaptar ao moderno Estado constitucional vigente, comprometido com o alargamento da cidadania e a realização dos direitos fundamentais ${ }^{50}$.

Pelo discorrido, percebe-se que o desenvolvimento do fenômeno ativista na função jurisdicional é o resultado da ampliação do Poder Judiciário. Não obstante guarde semelhanças com a judicialização, o ativismo judicial mantém sua singularidade por ser uma escolha do interprete julgador, que com um comportamento proativo busca expandir os preceitos constitucionais. Realmente, essa atuação mais livre representa um risco à teoria pura da separação de poderes e, por tal razão, requer uma revisão do instituto monstesquiano para fins de manter a independência entre os Poderes, mas também promover a harmonia.

\subsection{O ATIVISMO JUDICIAL NO BRASIL}

O Brasil importou as bases conceituais do ativismo judicial, que compreendem o fenômeno, segundo Barroso, como "uma atitude, a escolha de um modo específico e proativo de interpretar a Constituição, expandindo o seu sentido e alcance"51. Ainda, consoante o referido autor, oativismo manifesta-se, notadamente, na aplicação direta da Constituição nos casos de omissão legislativa, na declaração de inconstitucionalidade de atos normativos emanados do legislador e na imposição de condutas ou abstenções ao Poder Público ${ }^{52}$.

50 MENDES, Gilmar Ferreira et al. Curso de direito constitucional, v. 2. São Paulo: Saraiva, 2009. p. 92-93.

51 BARROSO, Luís Roberto. Judicialização, Ativismo Judicial e Legitimidade Democrática. (Syn)Thesis. vol. 5, n. 1. Rio de Janeiro: Centro de Ciências Sociais da Universidade do Estado do Rio de Janeiro, p. 23-32, 2012. Disponível em: <http://www.e-publicacoes.uerj.br/index.php/synthesis/article/ view/7433/5388>. Acesso em: 14 out. 2018. p. 25.

52 BARROSO, Luís Roberto. Judicialização, Ativismo Judicial e Legitimidade Democrática. (Syn)Thesis. vol. 5, n. 1. Rio de Janeiro: Centro de Ciências Sociais da Universidade do Estado do Rio de Janeiro, p. 23-32, 2012. Disponível em: <http://www.e-publicacoes.uerj.br/index.php/synthesis/article/ view/7433/5388>. Acesso em: 14 out. 2018. p. 26. 
Todavia, impõe destacar que a conduta ativista não é absolutamente livre, pois deve se respaldar nas diretrizes constitucionais, conforme ensina Camargo:

\begin{abstract}
Não se trata, pois, de uma interpretação completamente livre do magistrado ao julgar o caso concreto, valendo-se de fontes desconhecidas ou com o escopo de fixar uma posição pessoal. Pelo contrário, consiste em uma postura menos severa e rígida em aplicar o direito positivo, pois se baseia principalmente na força normativa dos princípios constitucionais e da ponderação, a despeito de uma aplicação meramente consubstanciada na subsunção. (CAMARGO, 2016, p. 240) ${ }^{53}$.
\end{abstract}

A necessidade de impor limites para a atuação judiciária já era debatida desde o desenvolvimento da concepção que reconhece certo grau de criatividade na interpretação dos juízes. Aliás, para Cappelletti, há virtudes passivas no processo judicial, limites que fazem juiz ser juiz, tribunal ser tribunal. São elas: imparcialidade no julgamento, imparcialidade e independência no andamento processual e o princípio nemo judex sine actore, isto é, atitude passiva no que tange à iniciativa de ajuizamento. Desse modo, a criatividade interpretativa se dirige aos aspectos materiais do direito, sendo resguardada a ausência de criatividade no plano processual ${ }^{54}$.

No que toca o ativismo judicial, a doutrina brasileira fragmenta-se entre juristas que concebem o fenômeno de forma negativa eapoiadores do movimento, com uma visão positiva. Dentre os críticos, destaca-se a concepção de Lenio Streck, cujo teortranscreve-se:

53 CAMARGO, G. Z. Aspectos doutrinários favoráveis e desfavoráveis ao ativismo e à autocontenção judicial. Rev. Ciênc. Juríd. Soc. v. 19, n. 2. Umuarama: UNIPAR, jul./dez. 2016. p. 240.

54 CAPPELLETTI, Mauro. Juízes legisladores? trad. por Carlos Alberto Álvaro de Oliveira. Porto Alegre: Sergio Antonio Fabris Editor, 1993. p. 76-79. 
0 ativismo sempre é ruim para a democracia, porque decorre de comportamentos e visões pessoais de juízes e tribunais, como se fosse possível uma linguagem privada, construída à margem da linguagem pública. (STRECK, 2016, p. 724) ${ }^{55}$.

Streck afirma que as decisões ativistas estão impregnadas com tamanha discricionariedade que resta prejudicada a resposta previamente positivada na Constituição, o que promove insegurança jurídica e lesa a democracia e os direitos fundamentais assegurados ${ }^{56}$. Em sentido próximo, Martins, declara que o ativismo judicial "está trazendo muito maior insegurança do que certeza no Direito e na vida dos Direitos" 57.

Souza Neto e Daniel, por sua vez, apresentam rol de parâmetros que buscam calibrar a presunção de constitucionalidade dos atos e o grau de ativismo a ser empregado, pontuando que se trata de lista meramente exemplificativa. Resumidamente, indicam que deve ser observado o grau de legitimidade democrática do ato normativo, a proteção das minorias estigmatizadas que não são alcançadas no processo político majoritário, a relevância do direito fundamental em jogo, como também é necessária aadoção de postura de autocontenção judicial para o caso de ausência de tecnicidade sobre determinadas áreas ${ }^{58}$. Concerne, por certo,

55 STRECK, Lenio Luiz. Entre o ativismo e a judicialização da política: a difícil concretização do direito fundamental a uma decisão judicial constitucionalmente adequada. Espaço Jurídico Journal of Law [EJJL], v. 17, n. 3, 2016. p. 724 .

56 STRECK, Lenio Luiz. Entre o ativismo e a judicialização da política: a difícil concretização do direito fundamental a uma decisão judicial constitucionalmente adequada. Espaço Jurídico Journal of Law [EJJL], v. 17, n. 3, 2016. p. 730.

57 DA SILVA MARTINS, Ives Gandra. 0 ativismo judicial e a ordem constitucional. Revista Brasileira de Direito Constitucional, v. 18, n. 1, 2011. p. 34.

58 DE SOUZA NETO, Cláudio Pereira; SARMENTO, Daniel. Notas sobre jurisdição constitucional e democracia: a questão da" última palavra" e alguns parâmetros de autocontenção judicial. Revista Quaestio Iuris, v. 6, n. 02, 2013. p. $149-175$. 
em tentativa de introduzir uma ideia de ativismo judicial mais cauteloso e dependente do Poder Legislativo.

Sob outra perspectiva, os defensores do ativismo judicial reconhecem sua importância para fins de concretização de direitos fundamentais não regulamentados no âmbito infraconstitucional pelo Legislativo, ou negligenciados pelo Poder Público. ConsoanteBranco, não se pode atribuir conotação ativista pejorativa à atuação do Judiciário se:

[...] interfira em alguma medida na execução de políticas públicas, se em certas circunstâncias ele supera decisões tomadas pelos canais político-representativos, sem outras ocasiões supre omissões dos poderes políticos que ofendem direitos fundamentais e se, ao exercer a jurisdição constitucional, por vezes é levado a ir além da mera função de legislador negativo, nada disso é, por si só, evidência de atuação desbordante do princípio da separação de poderes ou das exigências da democracia representativa. (BRANCO, 2011, p. 398) ${ }^{59}$.

Além disso, Barbosa ensina que não há desvio de finalidade do Judiciário pelo ativismo, haja vista que os juízes que agem de acordo com esse fenômeno estão apenas aplicando o direito, os direitos fundamentais em especial, direitos estes que gozam de autoexecutoriedade ${ }^{60}$. Afora isso, a existência de um Poder Legislativo que atua predominantemente conforme as vontades pessoais dos parlamentares ${ }^{61}$, faz com que atos e decisões que

59 BRANCO, Paulo Gustavo Gonet. Em busca de um conceito fugidio - o ativismo judicial. As novas faces do ativismo judicial. Salvador: Juspodivm, 2011. p. 387-401. p. 398.

60 BARBOSA, Hélder Fábio Cabral. A efetivação e o custo dos direitos sociais: a falácia da Reserva do possível. In:ANDRADE, Fernando Gomes de (org.). Estudos de direito constitucional. Recife: Edupe, 2011. p.151.

61 NETTO, Delfim. O oportunismo do Congresso. Carta Capital. [S. l]. 2017. Disponível em: <https://www.cartacapital.com.br/revista/961/o-oportunismo-do-congresso>. Acesso em 29 mai. 2018. 
buscam concretizar direitos fundamentais da sociedade sejam recebidos de forma positiva.

Por fim, merecedestaque o posicionamento de Barroso, o qual pretende elucidar que "o ativismo legitimamente exercido procura extrair o máximo das potencialidades do texto constitucional $^{62 " .}$.No decorrer de sua teoria, oreferido autor aponta críticas ao ativismo judicial e à crescente judicialização, sendo elas: risco para a legitimidade democrática, indevida politização da justiça e observância aos limites da capacidade institucional do Judiciário.

Tais objeções, contudo, são assentadas pelo próprio jurista quando afirma a legitimidade democrática das decisões pelo fundamento normativo, ou seja, pelo reconhecimento do poder político atribuído ao Judiciário pela Constituição, justificado na sua atuação técnica e imparcial, e pelo fundamento filosófico, que estabelece uma relação entre constitucionalismo e democracia que garante o equilíbrio entre a efetivação de direitos fundamentais e a vontade popular. Ademais, afasta o risco de politização da justiça quando o julgador atua em favor da democracia. E, finalmente, como solução aos limites da capacidade institucional do Judiciário, aponta que as decisões devem ser tomadas pelo órgão mais habilitado, cabendo ao Poder Judiciário exercer sua autolimitação espontânea ${ }^{63}$.

Nos últimos anos, o Supremo Tribunal Federal tende a adotar conduta proativa em diversas matérias, como no caso da expansão da vedação ao nepotismo aos Poderes Legislativo e Executivo, concretizada pela expedição da Súmula Vinculante $n^{\underline{0}}$

62 BARROSO, Luís Roberto. Constituição, democracia e supremacia judicial: direito e política no Brasil contemporâneo. Revista Jurídica da Presidência, v. 12 , n. 96 , p. $05-43,2010$, p. 11.

63 BARROSO, Luís Roberto. Judicialização, Ativismo Judicial e Legitimidade Democrática. (Syn)Thesis. vol. 5, n. 1. Rio de Janeiro: Centro de Ciências Sociais da Universidade do Estado do Rio de Janeiro, p. 23-32, 2012. Disponível em: <http://www.e-publicacoes.uerj.br/index.php/synthesis/article/ view/7433/5388>. Acesso em: 14 out. 2018. p. 27-30. 
13, buscando promover os princípios da moralidade e impessoalidade administrativa ${ }^{64}$. Alude-se, outrossim, como exemplo, a mudança de entendimento que o remédio constitucional Mandado de Injunção sofreu em 2007, pelo MI 670/ES, cuja adoção de uma concepção concretista ${ }^{65}$ possibilitou que, além de declarar a mora legislativa e fixar prazo para a edição da norma omissa, o Supremo Tribunal Federal aplicasse norma em analogia para suprir temporariamente a omissão. Com base nesse novo entendimento, a Corte, considerando a inércia legislativa, vincula regramento de hipótese similar ao caso concreto, garantindo o exercício do direito fundamental em questão e promovendo uma concepção positiva do ativismo ${ }^{66}$.

Em suma, em que pese parte da doutrina nacional aponte a existência do ativismo negativo, que é risco à democracia e à separação de poderes, deve se conceber o fenômeno de forma positiva quando objetiva concretizar as diretrizes constitucionais, que o limitam e legitimam. Para mais, o ativismo judicial poderá suprir omissões e adaptar o direito frentea novas exigências sociais $^{67}$. Dessarte, quando atua em favor da democracia e respeita os limites constitucionais, o ativismo apresenta-se como um mecanismo de promoção de direitos fundamentais.

64 BARROSO, Luís Roberto. Supremo Tribunal Federal, direitos fundamentais e casos difíceis. Revista Brasileira de Direito Constitucional, v. 19, n. 1, 2012. p. 115.

65 A técnica hermenêutica concretista foi desenvolvida por Konrad Hesse e parte da premissa de que a interpretação da Constituição deve considerar tanto texto constitucional quanto a realidade em que será aplicada a norma. (HESSE, Konrad. A força normativa da Constituição. trad. por Gilmar Ferreira Mendes. Porto Alegre: Sergio Antonio Fabris Editor, 1991. p. 22-23.).

66 NEVES, Daniel Amorim Assumpção. Ações constitucionais. ed. 3. Salvador: Editora JusPodivm, 2017. p. 130.

67 RAMOS, Elival Silva. Ativismo judicial: parâmetros dogmáticos. ed. 2. São Paulo: Saraiva, 2015. p. 112. 


\section{O ATIVISMO JUDICIAL NA JUSTIÇA ELEITORAL BRASILEIRA}

A Constituição Federal de 1988, em seu artigo 22, I e XIII, atribui ao Poder Legislativo a competência para legislar, com exclusividade, sobre matéria eleitoral e cidadania. Todavia, consoantevisto anteriormente no presente trabalho, o Direito Eleitoral sofre pela ausência de normativa em diversos institutos,resultado da negligência do Poder Legislativo ${ }^{68}$.

Assim, diante da inexistência de normas adequadas aos ideais democráticos contemporâneos, o Poder Judiciário eleitoral, extrapolando sua função jurisdicional, supre as omissões legislativas, configurando a prática de ativismo judicial nessa Justiça especializada ${ }^{69}$.

Desta feita, será verificado, cautelosamente, se essa atividade judiciária ativa poderá apresentar risco à democracia nacional. Após, analisar-se-á o fenômeno ativista no Tribunal Superior Eleitoral e no Supremo Tribunal Federal em matéria eleitoral.

Ao final, o estudo demonstrará os contornos normativos que o ativismo judicial ganha na área eleitoral, devido às peculiaridades de sua aplicação. Nessa trilha, impõe-se a reflexão sobre os mecanismos capazes de garantir legitimidade para a função normativa da Justiça Eleitoral, o que se realizará nas próximas páginas.

68 MACEDO, Elaine Harzheim. A função normativa da Justiça Eleitoral brasileira no quadro da separação dos poderes. Revista do Instituto do Direito Brasileiro, p.13871-13884, 2013. Disponível em: <http://cidp.pt/publicacoes/ revistas/ridb/2013/12/2013_12_13871_13884.pdf> Acesso em: 25 set. 2018. p. 13872-13873.

69 MACEDO, Elaine Harzheim. A função normativa da Justiça Eleitoral brasileira no quadro da separação dos poderes. Revista do Instituto do Direito Brasileiro, p.13871-13884, 2013. Disponível em: <http://cidp.pt/publicacoes/ revistas/ridb/2013/12/2013_12_13871_13884.pdf> Acesso em: 25 set. 2018. p. $13872-13873$. 


\subsection{A EXPERIÊNCIA JUDICIAL ATIVISTA NA JUSTIÇA ELEITORAL}

Haverá ativismo judicial quandojuízes, no exercício de sua função típica, extrapolam os limites da lei positivada suprindo omissões ou inovando o ordenamento jurídico. 0 objetivo desse fenômeno, para Barroso, é promover direitos fundamentais negligenciados pelos outros Poderes ${ }^{70}$, atribuindo ao Judiciário, no exercício de suas funções, caráter representativo dos anseios sociais $^{71}$.

Além disso, sob o argumento da efetivação de direitos, não raro, os órgãos judiciários proferem decisões contramajoritárias também, quesão julgamentos que declaram a inconstitucionalidade de leis (decisões majoritárias tomadas pelo Congresso em representação, em tese, da vontade popular) e de atos do Poder Executivo (cujo chefe foi eleito pela decisão da maioria absoluta dos cidadãos $)^{72}$.

A atuação judicial ativa, seja no exercício do papel representativo ou contramajoritário, de acordo com a crítica, implicaria na construção da juristo-cracia, em substituição à demo-cracia ${ }^{73}$. Ou seja, a democracia, que pauta-se na representação da vontade popular, estaria em risco ante o ativismo judicial, pois esse se baseia na vontade jurisdicional.

Porém, com o devido respeito a esse posicionamento, calha ressaltar que a Constituição Federal de 1988, ao prever a teoria da separação de poderes no artigo $2^{\circ}$, compreendida como o

70 BARROSO, Luís Roberto. Constituição, democracia e supremacia judicial: direito e política no Brasil contemporâneo. Revista Jurídica da Presidência, v. 12 , n. 96, p. 05-43, 2010, p. 11.

71 BARROSO, Luís Roberto. Curso de direito constitucional contemporâneo. ed. 4. São Paulo: Editora Saraiva, 2013. p. 447.

72 BARROSO, Luís Roberto. Curso de direito constitucional contemporâneo. ed. 4. São Paulo: Editora Saraiva, 2013. p. 446-447.

73 STRECK, Lenio Luiz. Entre o ativismo e a judicialização da política: a difícil concretização do direito fundamental a uma decisão judicial constitucionalmente adequada. Espaço Jurídico Journal of Law [EJJL], v. 17, n. 3, p. 721-732, 2016. p. 722. 
sistema de freios e contrapesos, conferiu a todos os Poderes alternativas de convergência com os demais, para fins de suprir as necessidades estatais e sociais e promover a harmonia. Em linhas claras, ao atuar suprindo omissões, o Poder Judiciário atende um anseio popular não observado pela negligência do Poder Legislativo ${ }^{74}$.

Outrossim, tão somente para afirmar que não há nenhuma lesão à democracia, cabe mencionar que o posicionamento decorrente de decisão judicial ativista poderá ser superado pela edição de norma posterior pelo Poder Legislativo ${ }^{75}$. Trata-se, em verdade, nesse caso, da observância da democracia representativa tradicional, pelo sistema jurídico brasileiro, diante da atuação legislativa típica ${ }^{76}$.

No que se refere às decisões contramajoritárias, há de se considerar que os interesses minoritários também compõe a democracia, portanto, uma vez observados, a reforçam, não denegam. Para mais, ao reconhecer que a democracia não se resume ao princípio majoritário, Barroso propõe "proteger valores e direitos fundamentais, mesmo que contra a vontade circunstancial de quem tem mais votos"77. Assim, busca-se a concretização da

74 MACEDO, Elaine Harzheim; SOARES, Rafael Morgental. O poder normativo da Justiça Eleitoral e a separação dos poderes: um paradigma democrático. Direitos fundamentais e democracia II. Florianópolis: Conpedi, p. 265293, 2014. p. 265.

75 MACEDO, Elaine Harzheim; SOARES, Rafael Morgental. O poder normativo da Justiça Eleitoral e a separação dos poderes: um paradigma democrático. Direitos fundamentais e democracia II. Florianópolis: Conpedi, p. 265293, 2014. p. 266.

76 LIMA, Rodrigo Britto Pereira. Reforma política e criação do direito pelo Tribunal Superior Eleitoral. In: MACHADO, José Amilcar (Coord.). Jornada de Direito Eleitoral das Escolas de Magistratura Federal, v. 20. Brasília: Tribunal Regional Federal da 1a Região, ESMAF, p. 190-201. jun. 2013. p. 192.

77 BARROSO, Luís Roberto. Judicialização, Ativismo Judicial e Legitimidade Democrática. (Syn)Thesis. vol. 5, n. 1. Rio de Janeiro: Centro de Ciências Sociais da Universidade do Estado do Rio de Janeiro, p. 23-32, 2012. Disponível em: <http://www.e-publicacoes.uerj.br/index.php/synthesis/article/ view/7433/5388>. Acesso em: 14 out. 2018. p. 28. 
soberania popular, que é de titularidade exclusivado povo em sua universalidade, não dosmeros interesses pessoais dos representantes da maioria ${ }^{78}$. Nesse passo, merece destaque o parecer de Ribeiro, cujo teor cumpre transcrever:

E o êxito da missão da Justiça Eleitoral se amplia e ganha maiores lastros históricos quanto mais se dispuser a sair da inércia, tendo que entrar em campo, por seus próprios impulsos, se outros faltarem, para evitar o envilecimento da disputa eleitoral, cumprindo assumir posição preventiva e mais espontânea, não deixando conspurcar a vontade do eleitorado, pelas formas ardilosas, sofisticas e também mais ousadas, aumentando, assim, o desafio que lhe assiste enfrentar, com o ânimo combativo e dignificante desempenho. (RIBEIRO, 1990, p. 133) ${ }^{79}$.

Sendo assim, quando o magistrado atua extrapolando suas funções, mas visando promover os preceitos constitucionais, em favor da soberania popular, objetiva o fortalecimento darepública e o progressoda democracia. Com base nessa fundamentação que a atuação dos tribunais superiores nacionais motivam suas decisões ativistas ${ }^{80}$, inclusive em matéria eleitoral ${ }^{81}$, o que será observado na análise de exemplos que seguem.

78 ZILIO, Rodrigo López. Limites e vedações da pré-campanha eleitoral conforme a Lei 13.165/15. Conjur, [S. l.], n.p, 2016. Disponível em: <https:// www.conjur.com.br/2016-set-08/rodrigo-zilio-limites-vedacoes-pre-campanha-eleitoral>. Acesso em: 24 out. 2018.

79 RIBEIRO, Fávila. Pressupostos constitucionais do direito eleitoral: no caminho da sociedade participativa. Porto Alegre: Sergio Antonio Fabris Editor, 1990. p. 133.

80 BARROSO, Luís Roberto. Judicialização, Ativismo Judicial e Legitimidade Democrática. (Syn)Thesis. vol. 5, n. 1. Rio de Janeiro: Centro de Ciências Sociais da Universidade do Estado do Rio de Janeiro, p. 23-32, 2012. Disponível em: <http://www.e-publicacoes.uerj.br/index.php/synthesis/article/ view/7433/5388>. Acesso em: 14 out. 2018. p. 28.

81 LIMA, Rodrigo Britto Pereira. Reforma política e criação do direito pelo Tribunal Superior Eleitoral. In: MACHADO, José Amilcar (Coord.). Jornada de Direito Eleitoral das Escolas de Magistratura Federal, v. 20. Brasília: Tribunal Regional Federal da 1a Região, ESMAF, p. 190-201. jun. 2013. p. 197. 
De acordo com Zilio, coligação é uma união formal, de caráter transitório, de partidos políticos, para fins de promoção de campanha, tanto para eleições majoritárias quanto proporcionais ${ }^{82}$. A verticalização das coligações é um conceito que busca promover certa coerência nos arranjos políticos, pois não permite que as reuniões se formem por meros interesses regionais, buscando uma nacionalização das compatibilizações de ideologias partidárias. Após o processo de redemocratização do país, o instituto foi previsto na Lei n. 8.713/1993 como uma faculdade dos partidos políticos, que deveriam observar a vedação para coligações diferentes na mesma circunscrição, isto é, no mesmo Estado ${ }^{83}$.

Ato contínuo, foi editada a Lei n. 9.504/1997 que, apesar de trazer diversos avanços ao Direito Eleitoral, autorizou a formação de diferentes coligaçõesnas eleições proporcionais, desde que pertencentes à mesma coligação do pleito majoritário ou incluíssepartido político que não possuia candidatura a cargo do Executivo. Ocorre que, em 2002, o Tribunal Superior Eleitoral recebeu consulta questionando sobre a possibilidade de coligações distintas para disputa da Presidência e do cargo de Governador. Por meio do exercício de sua função consultiva e de forma ativista, a Corte Eleitoral respondeu o questionamento pela edição da Resolução n. 20.993/2002, dispondo que deveria existir simetria entre o pleito majoritário federal e estadual, em respeito ao requisito da circunscrição, previsto no artigo 6으 da Lei n. 9.504/1997, e ao caráter nacional dos partidos políticos, conforme direciona o artigo 17, I, da Constituição Federal de 1988. Tal entendimento, embora, em certa medida, restringisse

82 ZILIO, Rodrigo López. Direito eleitoral. ed. 5. Porto Alegre: Verbo Jurídico, 2016. p. 111.

83 MARCHETTI, Vitor; CORTEZ, Rafael. A judicialização da competição política: o TSE e as coligações eleitorais. Opinião Pública, v. 15, n. 2, n. p, 2009. Disponível em: < http://www.scielo.br/scielo.php?pi$\mathrm{d}=$ S0104-62762009000200006\&script=sci_arttext\&tlng=ES>. Acesso em: 25 out. 2018. 
a autonomia partidária, fortalecia a república pelo respeito à nacionalidade das agremiações ${ }^{84}$.

A valer, os partidos políticos não possuíam interesse na manutenção dessa orientação, tendo em vista que inviabilizava o jogo partidário e prejudicava a regionalização necessária às reeleições. Dessa forma, por iniciativa do Senado Federal, foi protocolada a Proposta de Emenda à Constituição n. 04/02, que visava alterar o texto do $\$ 1^{\circ}$ do artigo 17 para incluir a coligação no rol de questões atinentes à autonomia partidária e desvinculá-la das candidaturas federais, estaduais e municipais, contrariando a consulta realizada. A referida proposta obteve aprovação na Câmara dos Deputados apenas em 2006, quando se aproximou o novo pleito eleitoral, recebendo o número de ordem 52. Conquanto, sua aplicação somente foi possível em 2010, em consideração ao princípio da anualidade da eleitoral ${ }^{85}$. Segundo Macedo e Soares, a Emenda Constitucional n. 52/02 apresenta regime que concebe"coligações inconsistentes e contraditórias"86.

Em 2017, pela Emenda Constitucional n. 97, que somente entrará em vigor em 2020, houve a vedação para coligações proporcionais, sendo liberadas as majoritárias, sem obrigatoriedade de vinculação ao pleito federal, estadual e municipal, o que fez persistir a inconsistência encontrada no sistema.Sem embargodo comportamento congressista ter atribuído novos traços às coligações, no referido caso é possível perceber a conduta ativista do

84 MARCHETTI, Vitor; CORTEZ, Rafael. A judicialização da competição política: o TSE e as coligações eleitorais. Opinião Pública, v. 15, n. 2, n. p, 2009. Disponível em: < http://www.scielo.br/scielo.php?pi$\mathrm{d}=$ S0104-62762009000200006\&script=sci_arttext\&tlng=ES>. Acesso em: 25 out. 2018.

85 MARCHETTI, Vitor; CORTEZ, Rafael. A judicialização da competição política: o TSE e as coligações eleitorais. Opinião Pública, v. 15, n. 2, n. p, 2009. Disponível em: < http://www.scielo.br/scielo.php?pi$\mathrm{d}=$ S0104-62762009000200006\&script=sci_arttext\&tlng=ES >. Acesso em: 25 out. 2018.

86 MACEDO, Elaine Harzheim; SOARES, Rafael Morgental. O poder normativo da Justiça Eleitoral e a separação dos poderes: um paradigma democrático. Direitos fundamentais e democracia II. Florianópolis: Conpedi, p. 265-293, 2014. p. 291. 
Judiciário eleitoral com vistas àpromoção das bases republicanas, protagonizando o caráter nacional dos partidos políticos ${ }^{87}$.

Elenca-se, como segunda exemplificação, o caso da inelegibilidade reflexa do artigo 14, §7ํㅡ, da Constituição Federal de 1988, hipótese que inviabiliza novas candidaturas de cônjuge ou companheiro e de parentes consanguíneos ou afins, até segundo grau ou por adoção, dos Chefes do Poder Executivo, em todos os níveis ${ }^{88}$. Em 2004, por decisão ativista, o Tribunal Superior Eleitoral estendeu a inelegibilidade reflexaaos casais homossexuais, no RESPE 24.564/PA, com relatoria do Ministro Gilmar Mendes, quando a união homoafetiva sequer era reconhecida na comunidade jurídica ${ }^{89}$.

Outro relevante caso de atitude ativista do Tribunal Superior Eleitoral foi as manifestações acerca do instituto da fidelidade partidária, despontadas a partir de 2007, com a chancela do Supremo Tribunal Federal. Ressalta-se que a Constituição Federal de 1988 pouco regulamentou as questões que envolvem a perda do mandato eletivo, além do rol do seu artigo 55. Frente a isso, o Tribunal Superior Eleitoral foi consultado, oportunidade que editou a Resolução n. 22.526/2007 em resposta. Por esse ato, estabeleceu que os partidos políticos tivessem o direito de preservar a vaga do parlamentar infiel e indicou hipóteses de justa causa que autorizavam a troca de legenda, sem perda do mandato ${ }^{90}$.

87 MARCHETTI, Vitor; CORTEZ, Rafael. A judicialização da competição política: o TSE e as coligações eleitorais. Opinião Pública, v. 15, n. 2, n. p, 2009. Disponível em: < http://www.scielo.br/scielo.php?pi$\mathrm{d}=$ S0104-62762009000200006\&script=sci_arttext\&tlng=ES>. Acesso em: 25 out. 2018.

88 ZILIO, Rodrigo López. Direito eleitoral. ed. 5. Porto Alegre: Verbo Jurídico, 2016. p. 199.

89 DIAS, Maria Berenice. Justiça não se curva à omissão do legislador. Conjur, [S.l.], n. p, 2010. Disponível em: <https://www.conjur.com.br/2010-mar-06/ justica-nao-curva-omissao-legislador-faz-justica>. Acesso em 29 mai. 2018.

90 SOUSA, Anne Calland Serra de. Fidelidade partidária sob a perspectiva do ativismo judicial nas decisões do Supremo Tribunal Federal. In: OLIVEIRA, Daniel Carvalho et al. Temas de Direito Eleitoral: coletâneas de artigos. Teresina: Editora Quimera, p. 11-61, 2013. p. 35. 
Com base na Resolução n. 22.526/2007, foram impetrados mandados de segurança (MS 26.602/DF, MS 26.603/DF e MS 26.604/DF) buscando a perda dos mandatos dos parlamentares enquadrados como infiéis. Apesar de não ser a ação específica, o Supremo Tribunal Federal, de forma representativa, em controle difuso, analisou a constitucionalidade da referida resolução, reconhecendo as orientações do Tribunal Superior Eleitoral como constitucionais e afirmando que preservariam a legitimidade do processo eleitoral, pois respeitavam a vontade do eleitor e fortaleciam as agremiações partidárias ${ }^{91}$.

Como se não bastasse, a Corte recomendou a aplicação, em analogia, dos artigos 3ํa 7ํ da Lei Complementar n. 64/1990 para o processo de infidelidade partidária e modulou os efeitos da decisão de forma pretérita, estabelecendo como marco a publicação da Resolução n. 22.526/2007, cujo conteúdo, atualmente, está transcrito na Resolução n. 22.610/2007 ${ }^{92}$. Destarte, nota-se que, além de criar os requisitos para caracterização da fidelidade partidária, o Judiciário indicou o procedimento cabível para futuras demandas que envolvessem o instituto.

A título de experiência ativista contramajoritária atualizada, relaciona-se o ED-RESPE n. 139-25/RS, de 2016, que apontou a virada de jurisprudência do Tribunal Superior Eleitoral quanto ao registro de candidatura sub judice, para fins de impor novos limitesaos atos de campanha dos candidatos que obtiveram o registro indeferido pela Corte Eleitoral, ainda que seja possível manejar recursos, afastando a incidência da válvula de escape do artigo 16-A da Lei n. 9.504/1997. Esse posicionamento serviu deprecedente para impedir, de imediato, que o ex-presidente

91 SOUSA, Anne Calland Serra de. Fidelidade partidária sob a perspectiva do ativismo judicial nas decisões do Supremo Tribunal Federal. In: OLIVEIRA, Daniel Carvalho et al. Temas de Direito Eleitoral: coletâneas de artigos. Teresina: Editora Quimera, p. 11-61, 2013. p. 39-40.

92 SOUSA, Anne Calland Serra de. Fidelidade partidária sob a perspectiva do ativismo judicial nas decisões do Supremo Tribunal Federal. In: OLIVEIRA, Daniel Carvalho et al. Temas de Direito Eleitoral: coletâneas de artigos. Teresina: Editora Quimera, p. 11-61, 2013. p. 55. 
Luiz Inácio Lula da Silva,após o indeferimento de seu registro de candidatura pelo Tribunal Superior Eleitoral, prosseguisse campanha para o pleito majoritário de $2018^{93}$.

0 principal fundamento do comportamento ativista dos magistrados em matéria eleitoral é a omissão legislativa no que toca a estrutura da Justiça Eleitoral e os institutos que compõem esse ramo especializado. Para Zilio, a razão crucial dessa inércia decorre da utilização de uma lógica de autopreservação pelo legisladoreleitoral, que não busca tratar de forma mais adequada matérias que reflitam diretamente na formação da democracia representativa ${ }^{94}$.

Em tal grau que o Poder Legislativo apenas definiu os requisitos para obtenção da quitação eleitoral, pela edição Lei n. 12.034/2009, após decisão ativista do Tribunal Superior Eleitoral que atribuíra conceito ampliativo às multas eleitorais para expedição da quitação eleitoral somente com o adimplemento de todas as multas incidentes, nos termos da Resolução n. 21.823/2004 ${ }^{95}$. Da mesma forma ocorreu com as coligações partidárias, que apenas ganharam destaque no palco do Legislativo quando o Judiciário impôs limites para sua formatação ${ }^{96}$.

93 TSE indefere pedido de registro de candidatura de Lula à Presidência da República. Tribunal Superior Eleitoral, [S. l.], 01 set. 2018. Disponível em: < http://www.tse.jus.br/imprensa/noticias-tse/2018/Setembro/tse-indefere-pedido-de-registro-de-candidatura-de-lula-a-presidencia-da-republica>. Acesso em 05 nov. 2018.

94 ZILIO, Rodrigo López. Limites e vedações da pré-campanha eleitoral conforme a Lei 13.165/15. Conjur, [S.l.], n.p, 2016. Disponível em: <https:// www.conjur.com.br/2016-set-08/rodrigo-zilio-limites-vedacoes-pre-campanha-eleitoral>. Acesso em 29 mai. 2018.

95 MACEDO, Elaine Harzheim; SOARES, Rafael Morgental. O poder normativo da Justiça Eleitoral e a separação dos poderes: um paradigma democrático. Direitos fundamentais e democracia II. Florianópolis: Conpedi, p. 265-293, 2014. p. 289.

96 MARCHETTI, Vitor; CORTEZ, Rafael. A judicialização da competição política: o TSE e as coligações eleitorais. Opinião Pública, v. 15, n. 2, n.p, 2009. Disponível em: < http://www.scielo.br/scielo.php?pi$\mathrm{d}=$ S0104-62762009000200006\&script=sci_arttext\&tlng=ES>. Acesso em: 25 out. 2018. 


\subsection{O ATIVISMO JUDICIAL NA JUSTIÇA ELEITORAL COMO FUNÇÃO NORMATIVA}

Consoante ao já discorrido, o ativismo judicial funda-se, notadamente, da necessária suplementação de vácuos legislativos, seja pela complementação de regulamentação dos institutos, ou pela criação de direitos. No mesmo sentido é a produção jurisdicional ativa da Justiça Eleitoral. No entanto, impende destacar que as decisões ativistas desse ramo especializado são formadas por diversos meios jurídicos de resposta e, por suas peculiaridades, tomam contornos normativos ${ }^{97}$.

As decisões judiciais ativistas são, geralmente, constituídas em controle concentrado ou difuso de constitucionalidade, e, igualmente, podem se formular no exercício das funçõesconsultiva, no caso específico do Direito Eleitoral, e regulamentadora, típica atividade dos órgãos judiciais. Na Justiça Eleitoral, afunção consultiva está prevista no artigo 23, XII, e 30, VIII, do Código Eleitoral, e o poder regulamentador é substanciado no artigo 23, IX, do Código Eleitoral e no artigo 105 da Lei n. 9.504/199798.

A função consultiva, peculiaridade eleitoral, objetiva esclarecer o posicionamento dos tribunais às autoridades públicas e aos partidos políticos, por meio da edição de resoluções, pois não se trata de decisão judicial para merecer acórdão ${ }^{99}$. Outrossim, Zilio observa que:

A resposta à consulta não tem natureza normativa, ou seja, não vincula o Tribunal, o consulente

97 MACEDO, Elaine Harzheim. A função normativa da Justiça Eleitoral brasileira no quadro da separação dos poderes. Revista do Instituto do Direito Brasileiro, p.13871-13884, 2013. Disponível em: <http://cidp.pt/publicacoes/ revistas/ridb/2013/12/2013_12_13871_13884.pdf>. Acesso em: 25 set. 2018. p. 13875.

98 CASTRO, Edson de Resende. Teoria e prática do direito eleitoral. ed. 4, rev. atual. Belo Horizonte: Mandamentos, 2008. p. 61-62.

99 CASTRO, Edson de Resende. Teoria e prática do direito eleitoral. ed. 4, rev. atual. Belo Horizonte: Mandamentos, 2008. p. 61. 
ou a terceiros; no mesmo norte, não tem conteúdo decisório. Apenas serve como orientação, em tese, sobre determinada matéria eleitoral, não significando que no julgamento de um caso concreto, quando observado o devido processo legal e o contraditório, o órgão consulente observará as diretrizes expostas na consulta. (ZILIO, 2016, p. $50-51)^{100}$.

Muito embora para as consultas não se guarde caráter vinculativo, importa observar que as decisões que as aplicam, dependendo do grau e da repercussão, poderão conferir vinculação obrigatória à matéria objeto do questionamento. Em via oposta está a função regulamentadora, uma vez que é atribuída às resoluções decorrentes de seu exercício força de lei ordinária, de acordo com posicionamento do Tribunal Superior Eleitoral na oportunidade do RESPE 1.943/RS ${ }^{101}$.

Ademais, em conformidade com o disposto no artigo 61 da Lei n. 9.096/1995, compete à Justiça Eleitoral expedir instruções quanto ao processo eleitoral por intermédio do poder regulamentador. Sob outras palavras, o Poder Judiciário eleitoral poderá regulamentar questões abaixo da lei, em especificação, mantendo-se sempre vinculado à lei ${ }^{102}$.

Nada obstante, a legislação eleitoral, em diversas situações, é insuficiente para prever parâmetros necessários para expedição de simples normas de instrução. Isso porque ocorre, por parte do Poder Legislativo, prevalência do exercício legiferante em causa

\footnotetext{
100 ZILIO, Rodrigo López. Direito eleitoral. ed. 5. Porto Alegre: Verbo Jurídico, 2016. p. 50-51.

101 CASTRO, Edson de Resende. Teoria e prática do direito eleitoral. ed. 4, rev. atual. Belo Horizonte: Mandamentos, 2008. p. 62.

102 MACEDO, Elaine Harzheim. A função normativa da Justiça Eleitoral brasileira no quadro da separação dos poderes. Revista do Instituto do Direito Brasileiro, p.13871-13884, 2013. Disponível em: <http://cidp.pt/publicacoes/ revistas/ridb/2013/12/2013_12_13871_13884.pdf>. Acesso em: 25 set. 2018. p. 13876.
} 
própria, até mesmo pela manutenção de um comportamento omisso pertinente aos interesses políticos partidários ${ }^{103}$.

Diante desse quadro, sob o aparato da imparcialidade e apartidarismo da Justiça Eleitoral, o poder regulamentador, com suporte nos comportamentos ativistas dos magistrados, adentra na esfera típica de produção legislativa e transcende para o caráter de poder normatizador ${ }^{104}$. Esse agir normativo distingue-se da mera regulamentação, haja vista que sua contribuição não presta para estabelecer elementos para o cumprimento da lei, mas sim para fazer a lei, em sentido material. Assim, a função normativa, constituída pelo ativismo judicial, torna-se remédio imediato para as omissões legislativas em matéria eleitoral ${ }^{105}$.

Em reflexão ao poder normatizador da Justiça Eleitoral, Macedo e Soares mencionam que é possível desenvolver críticas a essa transformação, como o reconhecimento que o processo de edição de resolução normativa é distinto da produção legislativa, que a competência legislativa sobre matéria eleitoral é exclusiva da União e, por fim, que o Tribunal Superior Eleitoral já controla a legislação pela atuação judiciária.

Porém, logo após, os autores apresentam contrapontos a tais dilemas, afirmando que as resoluções formuladas sob o exercício do poder normativo são objetos de controle de constitucionalida-

103 MACEDO, Elaine Harzheim. A função normativa da Justiça Eleitoral brasileira no quadro da separação dos poderes. Revista do Instituto do Direito Brasileiro, p.13871-13884, 2013. Disponível em: <http://cidp.pt/publicacoes/ revistas/ridb/2013/12/2013_12_13871_13884.pdf>. Acesso em: 25 set. 2018. p. 13873-13875.

104 MACEDO, Elaine Harzheim. A função normativa da Justiça Eleitoral brasileira no quadro da separação dos poderes. Revista do Instituto do Direito Brasileiro, p.13871-13884, 2013. Disponível em: <http://cidp.pt/publicacoes/ revistas/ridb/2013/12/2013_12_13871_13884.pdf> Acesso em: 25 set. 2018. p. 13875.

105 MACEDO, Elaine Harzheim; SOARES, Rafael Morgental. O poder normativo da Justiça Eleitoral e a separação dos poderes: um paradigma democrático. Direitos fundamentais e democracia II. Florianópolis: Conpedi, p. 265-293, 2014. p. 279. 
de, o que assegura sua regularidade com o ordenamento jurídico e, especialmente, com os preceitos constitucionais. Além disso, declaram que o exercício do poder normativo pelo Judiciário eleitoral garantedemocracia, igualdade e pluralidade, corrompidas pela inércia do Poder Legislativo ${ }^{106}$.Em seguida, apontam que o poder normativo na Justiça Eleitoral desempenha dupla funcionalidade, basta ver queaprimora o Direito Eleitoral e estimulaa atuação legislativa típica. Nas palavras de Macedo e Soares:

A alternativa possível - dentro da separação de poderes, e não em ofensa a ela - é reconhecer o poder normativo da Justiça Eleitoral como contrapeso ao domínio do poder legislativo sobre as normas eleitorais: uma forma de aprimorar o sistema naquilo que a instância legislativa não tem condições de fazer; e instar o legislador ao movimento, nas situações em que a inércia é benéfica a seus agentes. (MACEDO; SOARES, 2014, p. 283) ${ }^{107}$.

À vista disso, a função normativa que o ativismo judicial propicia à Justiça Eleitoral busca, em verdade, minimizar os impactos negativos que a negligência do Poder Legislativo enseja no regime democrático e na forma republicana de Estado ${ }^{108}$. Ademais, ao passo que o Judiciário eleitoral exerce a função normativa agindo como terceiro desinteressado, promove igualdade, democracia e

106 MACEDO, Elaine Harzheim; SOARES, Rafael Morgental. O poder normativo da Justiça Eleitoral e a separação dos poderes: um paradigma democrático. Direitos fundamentais e democracia II. Florianópolis: Conpedi, p. 265-293, 2014. p. 282.

107 MACEDO, Elaine Harzheim; SOARES, Rafael Morgental. O poder normativo da Justiça Eleitoral e a separação dos poderes: um paradigma democrático. Direitos fundamentais e democracia II. Florianópolis: Conpedi, p. 265-293, 2014. p. 283.

108 MACEDO, Elaine Harzheim; SOARES, Rafael Morgental. O poder normativo da Justiça Eleitoral e a separação dos poderes: um paradigma democrático. Direitos fundamentais e democracia II. Florianópolis: Conpedi, p. 265-293, 2014. p. 285. 
viabiliza o resgate da representatividade, visto que, quanto maior é o controle sob os atos do sujeito passivo (políticos e agremiações), mais primazia se atribui à liberdade de escolha do eleitor ${ }^{109}$.

\subsection{OS MECANISMOS DE LEGITIMAÇÃO DEMOCRÁTICA DA FUNÇÃO NORMATIVA DA JUSTIÇA ELEITORAL}

A essencialidade do ativismo judicial na Justiça Eleitoral ampara a transição da função regulamentar para normativa ${ }^{110}$. Todavia, em que pese o reconhecimento do ativismo positivo nessa área especializada por todo já exposto, é concebível pensar em instrumentos capazes de garantir legitimidade democrática à função normativa eleitoral, afastando eventual incerteza jurídica e instrumentalizando a mais ampla democracia representativa e participativa.

Uma das razões para o incremento de mecanismos de legitimação no processo eleitoral decorre da atuação da sociedade aberta dos intérpretes da Constituição, que reconhece as forças pluralistas da sociedade, porquanto representam um pedaço da publicidade e da realidade da Constituição. Häberle, em sua teoria pluralista, afirma que uma Constituição se estrutura não apenas no Estado em sentido estrito, mas também na esfera pública; portanto, não pode tratar as forças sociais e privadas como meros objetos, deve-se, em realidade, integrá-las ativamente como sujeitos ${ }^{111}$.

${ }^{109}$ MACEDO, Elaine Harzheim; SOARES, Rafael Morgental. O poder normativo da Justiça Eleitoral e a separação dos poderes: um paradigma democrático. Direitos fundamentais e democracia II. Florianópolis: Conpedi, p. 265-293, 2014. p. 285.

110 MACEDO, Elaine Harzheim. A função normativa da Justiça Eleitoral brasileira no quadro da separação dos poderes. Revista do Instituto do Direito Brasileiro, p.13871-13884, 2013. Disponível em: <http://cidp.pt/publicacoes/ revistas/ridb/2013/12/2013_12_13871_13884.pdf>. Acesso em: 25 set. 2018. p. 13876.

111 HÄBERLE, Peter. A sociedade aberta dos intérpretes da Constituição: contribuição para a interpretação pluralista e "procedimental" da Constituição. Trad. Gilmar Ferreira Mendes. Porto Alegre: Sergio Antonio Fabris Editor, 1997. p. 33. 
Ainda, o autor supracitado defende que a hermenêutica constitucional não se limita aos intérpretes corporativos ou autorizados jurídica ou funcionalmente pelo Estado. Häberle destaca que o povo é também um elemento pluralista para a interpretação legitimadora do processo constitucional, atuando como partido político, como opinião científica, como grupo de interesse, como cidadão. Ademais, afirma que a "competência objetiva para interpretação constitucional é um direito da cidadania [...]"112.

Em reflexão à sociedade aberta, Mendes et al. apontam que, se vivemos num Estado Democrático, a leitura da Constituição deve ser realizada em voz alta e à luz do dia, em consagração ao processo público e republicano, em um diálogo pluralista, ou seja, com diversos atores sociais ${ }^{113}$. Inclusive, impende trazer à baila que a Constituição Federal de 1988 apresenta o pluralismo como fundamento da República, nos termos do seu artigo $1^{\circ}$, V.

Nessa senda, adequa-se também à necessidade de legitimação democrática da força normativa judicial o processo de judicialização das questões dos fatores reais do poder. Esses fatores são força ativa e eficaz que funda todas as leis e instituições jurídicas e, diante disso, carecemdo fortalecimento de sua representatividade, sob pena da Constituição se transformar em simples folha de papel $^{114}$.

Isso posto, os mecanismos a serem adotados buscam outorgar maior legitimidade para o Poder Judiciário exercer função normativa, pois asseguram participação social, transparência e efetividade dos direitos fundamentais às decisões judiciais ${ }^{115}$.

112 HÄBERLE, Peter. A sociedade aberta dos intérpretes da Constituição: contribuição para a interpretação pluralista e "procedimental" da Constituição. Trad. Gilmar Ferreira Mendes. Porto Alegre: Sergio Antonio Fabris Editor, 1997. p. 37.

${ }^{113}$ MENDES, Gilmar Ferreira et al. Curso de direito constitucional, v. 2. São Paulo: Saraiva, 2009. p. 142.

${ }^{114}$ LASSALLE, Ferdinand. 0 que é uma Constituição?.Trad. Walter Stönner. São Paulo: Edições e Publicações Brasil, 1933. p. 17.

115 WELSCH, Gisele Mazzoni. Legitimação democrática do poder judiciário no novo Código de Processo Civil. São Paulo: Editora Revista dos Tribunais, 2016. p. 185. 
A partir disso, indica-se, a título de exemplo, como meios de legitimação a serem utilizados na função normativa da Justiça Eleitoral a figura do amicus curiae e a realização de audiências públicas, que se prestarão a uma análise mais cuidadosa nas próximas linhas.

Oamicus curiae, previsto no artigo 138 do Código de Processo Civil,está relacionado ao terceiro que intervém no processo para fornecer subsídios a fim de aprimorar a qualidade da decisão, de forma espontânea ou por provocação do órgão jurisdicional ${ }^{116}$. Segundo Cunha, a participação dessa figura no processo objetivo de controle de constitucionalidade pluraliza o debate e viabiliza maior abertura no seu procedimento e na interpretação constitucional ${ }^{117}$.

Na Justiça Eleitoral, contudo, a Resolução n. 23.478/2016, por seu artigo $5^{\circ}$, veda a utilização desse mecanismo no processo eleitoral, pois sua intervenção tem o potencial de retardar o julgamento do feito, o que prejudica a celeridade processual, caro princípio eleitoral ${ }^{118}$. Assimilar a imprescindibilidade de celeridade no rito processual eleitoral é necessário, haja vista que muitas classes processuais dependem dos prazos de campanha eleitoral, como exemplo,das convenções, dos registros de candidatura, da diplomação, e etc ${ }^{119}$. Ocorre que, em contrapartida, há a república e a imperiosa missão de promover a mais ampla e legítima democracia.

Nesse sentido, Welsch ensina que a participação do amicus

116 DIDIER JR, Fredie et al. Curso de direito processual civil. ed. 17, v. 1. Salvador: Juspodivm, 2015. p. 522.

117 CUNHA, Jr., Dirley da. A intervenção de terceiros no processo de controle abstrato de constitucionalidade - a intervenção do particular, do colegitimado e do amicus curiae na ADIN, ADC e ADPF. Aspectos polêmicos e atuais sobre os terceiros no processo civil e assuntos afins. São Paulo: RT, 2004. p. 165.

118 REIS, Márlon et al. Processo Eleitoral e o novo CPC: aplicação imediata. ed. 2, rev. e atual. Salvador: Juspodivm, 2016. p. 66-67.

119 ZILIO, Rodrigo López. Direito eleitoral. ed. 5. Porto Alegre: Verbo Jurídico, 2016. p. 33. 
curiae atribui tecnicidade, segurança jurídica e justiça às decisões, em razão de consistir em elemento otimizador da legitimidade democrática dos atos judiciais, dado que aproxima o Poder Judiciário da sociedade ${ }^{120}$. Do mesmo modo, Reis pondera que o instituto poderá ser um instrumento de valiosa colaboração, em virtude de possuir relevância social pela pertinência da atuação de algumas entidades visando melhorar a qualidade das decisões da Justiça Eleitoral. Assim, conclui que o mecanismo do amicus curiae é plenamente compatível com o processo eleitoral, diante de sua finalidade social, cabendoà Corte Eleitoral modificar seu posicionamento ${ }^{121}$.

Já as audiências públicas, previstas no artigo 9oㅗㅇำ $1^{\circ}$, da Lei n. 9.868/1999, constituem procedimento que viabiliza a manifestação de terceiros com experiência na matéria, em processos de controle concentrado, para fins de prestar esclarecimento e contribuir para a fundamentação da decisão. Trata-se de mecanismo que, de forma similar ao anterior, garante o espaço democrático em demandas complexas, promovendo maior participação popular no processo ${ }^{122}$.

Cabe, com efeito, a utilização dos postulados normativos aplicativos da razoabilidade e da proporcionalidadepara selecionar o método democrático mais compatível com a demanda e o objetivo ativista buscado pelo julgador. A título de esclarecimento, para Ávila, razoabilidade pode ser utilizado de três formas, quais sejam: como equidade, que requer uma harmonização da norma geral com o caso individual; como congruência, que esta-

120 WELSCH, Gisele Mazzoni. Legitimação democrática do poder judiciário no novo Código de Processo Civil. São Paulo: Editora Revista dos Tribunais, 2016. p. 177.

121 REIS, Márlon et al. Processo Eleitoral e o novo CPC: aplicação imediata. ed. 2, rev. e atual. Salvador: Juspodivm, 2016. p. 67-68.

122 WELSCH, Gisele Mazzoni. Legitimação democrática do poder judiciário no novo Código de Processo Civil. São Paulo: Editora Revista dos Tribunais, 2016. p. 151-152. 
belece uma relação entre a regra e as condições fáticas; e como equivalência, que exige uma relação entre a medida adotada e o critério que a dimensiona ${ }^{123}$. 0 postulado normativo aplicativo da proporcionalidade, por sua vez, depende do estabelecimento de uma relação de meio e fim, após a verificação das normas em colisão. Estabelecido o meio e o fim, deve se passar por três fases, sendo estas: a adequação, a necessidade e a proporcionalidade em sentido estrito ${ }^{124}$.

Enfim, ressalta-seque mecanismos de legitimação democrática são meios que buscam a ampliação da participação popular, do debate e da tecnicidade das decisões judiciais, para fins de promover a democracia, segurança jurídica e a decisão mais adequada à realidade social ${ }^{125}$. A decisão judicial adequada e motivada, que éconstruída com o intento de promover direitos fundamentais e cidadania, reconhecendo a importância dos atores sociais, é legítima e democraticamente controlada ${ }^{126}$.

Nessa sorte, as decisões judiciais ativistas, mas pluralizadas pela participação popular, poderão servir de subsídio para processos posteriores similares, estabelecendo-se como precedente judicial, que projeta efeitos jurídicos ao futuro condicionando os indivíduos ${ }^{127}$. A objetividade da aplicação dos precedentes judiciais possui o condão, em melhor viés, de devolver celeridade ao

123 ÁVILA, Humberto. Teoria dos Princípios: da definição à aplicação dos princípios jurídicos. 5a Ed., revista e ampliada. São Paulo: Malheiros Editores LTDA, 2006. p. 139.

124 ÁVILA, Humberto. Teoria dos Princípios: da definição à aplicação dos princípios jurídicos. 5aㅡ Ed., revista e ampliada. São Paulo: Malheiros Editores LTDA, 2006. p. 160.

125 MATTOS, Paulo Todescan Lessa. O Novo Estado Regulador no Brasil: Eficiência e Legitimidade. São Paulo: Singular, 2006. p. 198.

126 WELSCH, Gisele Mazzoni. Legitimação democrática do poder judiciário no novo Código de Processo Civil. São Paulo: Editora Revista dos Tribunais, 2016. p. 151.

127 WELSCH, Gisele Mazzoni. Legitimação democrática do poder judiciário no novo Código de Processo Civil. São Paulo: Editora Revista dos Tribunais, 2016. p. 35. 
processo eleitoral, uma vez que estabelece certa previsibilidade do conteúdo decisório e reduz eventuais tautologias ou ambiguidades $^{128}$. Clarificando, se em um primeiro momento a celeridade é mitigada na Justiça Eleitoral pelos procedimentos dos mecanismos de legitimação, posteriormente, por outro lado, quando da formulação de decisão adequada, motivada e democrática, restabelece o ritmo processual pela possibilidade de subsunção dos processos similares no precedente.

Perante o narrado, conclui-se que a força normativa da Justiça Eleitoral, substanciada no ativismo judicial, é legítima quando objetiva concretizar direitos fundamentais, e se torna democrática quando amplia a participação dos atores sociais na formulação da motivação das decisões. Assim, o ativismo judicial na Justiça Eleitoral deve ser concebido como um remédio imediato para as negligências do Poder Legislativo. No entanto, juízes e tribunais de postura ativista não podem atuar de forma autônoma, cumprindo observar preceitos e procedimentos constitucionais para garantir segurança jurídica, transparência e democracia participativa e representativa.

\section{CONSIDERAÇÕES FINAIS}

A democracia brasileira é consagrada pela Constituição Federal de 1988 e possui como órgão indispensável para seu exercício a Justiça Eleitoral. A atuação dessa Justiça especializada busca efetivar a democracia representativa e participativa, instigando o fortalecimento da república.

Seus atos estão relacionados com o resguardo da regularidade do pleito eleitoral; como vivenciado em 2018, quando ajuizada ação junto ao Tribunal Superior Eleitoral para investigar a campanha do então candidato Jair Bolsonaro sobre supostas doações de serviços de empresas que compartilhavam fake news

128 REIS, Márlon et al. Processo Eleitoral e o novo CPC: aplicação imediata. ed. 2, rev. e atual. Salvador: Juspodivm, 2016. p. 173. 
com a intenção de prejudicar seu oponente, em tese conturbando a opinião do eleitorado. Caso evidenciada essa prática, à Justiça Eleitoral caberia condenar o candidato do Partido Social Liberal por abuso de poder econômico e uso indevido dos meios de comunicação, tornando-o inelegível.

Em que pese a essencialidade de suas atribuições, a Justiça Eleitoral padece com as omissões legislativas quanto sua organização e institutos, geralmente, justificadas pelos interesses tendenciosos políticos dos membros do Poder Legislativo. Diante desse quadro, o ativismo judicial apresenta-se como mecanismo capaz de suprir lacunas e efetivar direitos democráticos dos cidadãos.

Todavia, o fenômeno ativista judicial, concebido como movimento que sana omissões legislativas, cria direitos e promove outros negligenciados pelo Executivo, é duramente criticado, diante do risco que, em tese, apresenta à democracia, à segurança jurídica e à separação de poderes.

Impende ressaltar que o ativismo judicial, de fato, não importa uma conduta absolutamente livre dos magistrados, uma vez que é indispensável a observância aos preceitos constitucionais para resguardo do Estado Democrático de Direito. Sob outras linhas, quando o julgador atua efetivando direitos fundamentais, está legitimamente promovendo a democracia. Inclusive, a vinculação ao texto constitucional que assegurará segurança jurídica ao fenômeno.

No que toca à separação de poderes, impõe-se uma necessária revisão do instituto montesquiano para fins de compreender uma divisão de funções que resguarde a independência entre os Poderes, e impulsione a harmonia. Assim, o ativismo judicial não lesará as funções das demais forças estatais, mas sim, por outro lado, provocará a atuação efetiva e em conformidade com a Constituição, base da sociedade.

Nessa esteira, minimizados os riscos que o ativismo judicial poderia implicar e atribuindo-lhe faces positivas, pode-se com- 
preender que na Justiça Eleitoral, diante do abandono legislativo, esse comportamento tomará importante posição para o fortalecimento da república e efetivação da cidadania. Não se pretende, contudo, esvaziar o ativismo judicial de suas críticas, mas sim conceber que na Justiça Eleitoral, por suas peculiaridades, o fenômeno assume papel necessário e positivo.Aliás, os contornos normativos que o poder regulamentador recebe caracterizam a relevância da atuação ativista nesse ramo especializado.

Cumpre ressaltar que o comportamento ativo do Poder Judiciário eleitoral é o meio imediato para sanar as omissões complacentes do Legislativo e que, quando promovem os direitos fundamentais e a cidadania, fortalecem a república. Nessa situação, os mecanismos de legitimação democrática apresentam-se como mais um meio para garantir segurança jurídica e participação popular ao fenômeno.

A utilização dos mecanismos de legitimação democrática, como amicus curiae e audiências públicas, direciona ao cidadão, principal ator da democracia, o papel de contribuir para a formação do direito. Além disso, promove-se transparência ao processo judicial eleitoral, o que pode, em melhor aspecto, instigar a responsabilidade e o interesse eleitoral do cidadão, uma vez que aproxima o Estado da sociedade.

Há vedação para a utilização de certos mecanismos no processo judicial eleitoral, pois importariam na mitigação da celeridade do feito. No entanto, sopesando com os ganhos de ampliação da participação popular, da democracia e da transparência, certa morosidade no rito processual se torna infimamente prejudicial. De mais a mais, decisões adequadas, motivadas e pluralistas formam precedentes judiciais, que uniformizam posicionamentos e dinamizam o julgamento de casos similares, o que retoma agilidade à marcha processual.

Em linhas claras e objetivas: cabe à Justiça Eleitoral adotar todos os meios possíveis que, de alguma forma, possam viabilizar 
o exercício amplo da democracia. Com isso, é fundamental colocar o eleitor no ponto central dos holofotes, para fins de legitimar e democratizar o processo eleitoral lato sensu, intencionalmente negligenciado pelo Legislativo nacional.

Diante do exposto,conclui-se que o fenômeno ativista na Justiça Eleitoral assume relevante encargocom vistas à promoção dos fins constitucionais democráticos participativos da república. Contudo, importa esclarecer que o ativismo judicial é um instrumento imediato, que merece ser dispensado ao passo que o Poder Legislativo nacional entenda por atuar segundo a vontade popular, abandonando meros interesses políticos pessoais. Infelizmente, essa utópica situação dependerá de reforma política e cultural, por ora, inviável na atual conjuntura política nacional.

\section{REFERÊNCIAS}

ÁVILA, Humberto. Teoria dos Princípios: da definição à aplicação dos princípios jurídicos. 5 ${ }^{a}$ Ed., revista e ampliada. São Paulo: Malheiros Editores LTDA, 2006.

BARBOSA, Hélder Fábio Cabral. A efetivação e o custo dos direitos sociais: a falácia da Reserva do possível. In:ANDRADE, Fernando Gomes de (org.). Estudos de direito constitucional. Recife: Edupe, 2011.

BARROSO, Luís Roberto. Constituição, democracia e supremacia judicial: direito e política no Brasil contemporâneo. Revista Jurídica da Presidência, v. 12, n. 96, p. 05-43, 2010.

. Curso de direito constitucional contemporâneo. ed. 4. São Paulo: Editora Saraiva, 2013.

Interpretação e aplicação da Constituição: fundamentos de uma dogmática constitucional transformadora. São Paulo: Saraiva, 2009.

Judicialização, Ativismo Judicial e Legitimidade Democrática. (Syn)Thesis. vol. 5, n. 1. Rio de Janeiro: Centro de Ciências Sociais da Universidade do Estado do Rio de Janeiro, p. 23-32, 2012. Disponível em: <http://www.e-publicacoes.uerj.br/index.php/synthesis/article/ view/7433/5388>. Acesso em: 14 out. 2018.

Supremo Tribunal Federal, direitos fundamentais e casos difíceis.

Revista Brasileira de Direito Constitucional, v. 19, n. 1, 2012. 
BRANCO, Paulo Gustavo Gonet. Em busca de um conceito fugidio - o ativismo judicial. As novas faces do ativismo judicial. Salvador: Juspodivm, p. 387-401, 2011.

BRASIL, Supremo Tribunal Federal. Súmula Vinculante n. 13. Diário da Justiça Eletrônico. Poder Judiciário, Brasília, DF, 29 ago. 2008.

BRASIL. Constituição da República Federativa do Brasil, de 05 de outubro de 1988. Diário Oficial da União, Brasília, 05 de outubro de 1988.

BRASIL. Lei Complementar n. 64, de 18 de maio de 1990. Diário Oficial da União, Brasília, 18 de maio de 1990.

BRASIL. Lei n. 12.039, de 1ำ de outubro de 2009. Diário Oficial da União, Brasília, 1ำ de outubro de 2009.

BRASIL. Lei n. 13.105, de 16 de março de 2015. Diário Oficial da União, Brasília, 16 de março de 2015.

BRASIL. Lei n. 4.737, de 15 de julho de 1965. Diário Oficial da União, Brasília, 15 de julho de 1965.

BRASIL. Lei n. 8.713, de 30 de setembro de 1993. Diário Oficial da União, Brasília, 30 de setembro de 1993.

BRASIL. Lei n. 9.096, de 19 de setembro de 1995. Diário Oficial da União, Brasília, 19 de setembro de 1995.

BRASIL. Lei n. 9.504, de 30 de setembro de 1997. Diário Oficial da União, Brasília, 30 de setembro de 1997.

BRASIL. Resolução do Tribunal Superior Eleitoral n. 20.993, de 26 de fevereiro de 2002. Diário da Justiça. Poder Judiciário, Brasília, DF, 11 abr. 2002, seção 1, p. 115-118.

BRASIL. Resolução do Tribunal Superior Eleitoral n. 21.823, de 15 de junho de 2004. Diário da Justiça. Poder Judiciário, Brasília, DF, 05 jul. 2004, seção 1, p. 03.

BRASIL. Resolução do Tribunal Superior Eleitoral n. 22.526, de 27 de março de 2007. Diário da Justiça. Poder Judiciário, Brasília, DF, 08mai. 2007.

BRASIL. Resolução do Tribunal Superior Eleitoral n. 22.610, de 25 de outubro de 2007. Diário da Justiça. Poder Judiciário, Brasília, DF, 27 mar. 2008, seção 1, p. 11.

BRASIL. Resolução do Tribunal Superior Eleitoral n. 23.478, de 10 de maio de 2016. Diário da Justiça Eletrônico. Poder Judiciário, Brasília, DF, 15 jun. 2016. 
BRASIL. Supremo Tribunal Federal. Mandado de injunção n. 670-ES. Impetrante: Sindicato dos Servidores Policiais Civis do Estado do Espírito Santo. Impetrado: Congresso Nacional. Relatora: Ministra Rosa Weber. Brasília, 30 de outubro de 2008. Diário da Justiça Eletrônico, n. 206, out. 2008.

BRASIL. Supremo Tribunal Federal. Mandado de segurança n. 26.602-DF. Impetrante: Partido Popular Socialista. Impetrado: Presidente da Câmara dos Deputados. Relator: Ministro Eros Grau. Brasília, 16 de outubro de 2008. Diário da Justiça Eletrônico, n. 197, out. 2008.

BRASIL. Supremo Tribunal Federal. Mandado de segurança n. 26.603DF. Impetrante: Partido da Social Democracia Brasileira. Impetrado: Presidente da Câmara dos Deputados. Relator: Ministro Celso de Mello. Brasília, 18 de dezembro de 2008. Diário da Justiça Eletrônico, n. 241, dez. 2008.

BRASIL. Supremo Tribunal Federal. Mandado de segurança n. 26.604DF. Impetrante: Democratas. Impetrado: Presidente da Câmara dos Deputados. Relatora: Ministra Cármen Lúcia. Brasília, 02 de outubro de 2008. Diário da Justiça Eletrônico, n. 187, out. 2008.

BRASIL. Tribunal Superior Eleitoral. Embargos de declaração no recurso especial eleitoral n. 139-25-RS. Embargante: Ministério Público Eleitoral. Assistente do embargante: Altenir Rodrigues da Silva. Embargado: Lindomar Elias. Relator: Ministro Henrique Neves da Silva. Brasília, 28 de novembro de 2016. Publicado em sessão, 28 nov. 2016.

BRASIL. Tribunal Superior Eleitoral. Recurso especial eleitoral n. 24.564PA. Recorrentes: Dilermando Júnior Fernandes Lhamas, Izaias José Silva Oliveira Neto e Luiz Alfredo Amin Fernandes. Recorrida: Maria Eulina Rabelo de Sousa Fernandes. Relator: Ministro Gilmar Mendes. Brasília, 01 de outubro de 2004. Revista de jurisprudência do TSE, v. 17, tomo 1. p. 234.

BRASIL. Tribunal Superior Eleitoral. Recurso especial eleitoral n. 1.943RS. Relator: Ministro Pedro Paulo Pena E Costa. Brasília, 01 de janeiro de 1970. Publicado em sessão, 10 jul. 1952.

CAMARGO, G. Z. Aspectos doutrinários favoráveis e desfavoráveis ao ativismo e à autocontenção judicial. Rev. Ciênc. Juríd. Soc. v. 19, n. 2. Umuarama: UNIPAR, jul./dez. 2016.

CAPPELLETTI, Mauro. Juízes legisladores? trad. por Carlos Alberto Álvaro de Oliveira. Porto Alegre: Sergio Antonio Fabris Editor, 1993. 
CASTRO, Edson de Resende. Teoria e prática do direito eleitoral. ed. 4, rev. atual. Belo Horizonte: Mandamentos, 2008.

CITTADINO, Gisele. Poder Judiciário, ativismo judicial e democracia. Revista da Faculdade de Direito de Campos, v. 2/3, n. 2/3, p. 135144, 2001-2002. Disponível em: <http://bdjur.stj.jus.br/dspace/handle/2011/25512>. Acesso em: 13 out. 2018.

CUNHA, Jr., Dirley da. A intervenção de terceiros no processo de controle abstrato de constitucionalidade - a intervenção do particular, do colegitimado e do amicus curiae na ADIN, ADC e ADPF. Aspectos polêmicos e atuais sobre os terceiros no processo civil e assuntos afins. São Paulo: RT, 2004.

DA SILVA MARTINS, Ives Gandra. 0 ativismo judicial e a ordem constitucional. Revista Brasileira de Direito Constitucional, v. 18, n. 1, 2011.

DE SOUZA NETO, Cláudio Pereira; SARMENTO, Daniel. Notas sobre jurisdição constitucional e democracia: a questão da" última palavra" e alguns parâmetros de autocontenção judicial. Revista Quaestio Iuris, v. 6, n. 02, 2013.

DIAS, Maria Berenice. Justiça não se curva à omissão do legislador. Conjur, [S.l.], n. p, 2010. Disponível em: <https://www.conjur.com. br/2010-mar-06/justica-nao-curva-omissao-legislador-faz-justica>. Acesso em 29 mai. 2018.

DIDIER JR, Fredie et al. Curso de direito processual civil. ed. 17, v. 1. Salvador: Juspodivm, 2015.

FACCHINI NETO, Eugênio. 0 judiciário no contexto do poder: uma abordagem de direito comparado. Revista Ajuris, v. 37, n. 118, junho/2010. Disponível em: <https://bdjur.tjdft.jus.br/xmlui/handle/123456789/8569>. Acesso em: 16 out. 2018.

FICO, Carlos. História do Brasil contemporâneo: da morte de Vargas aos dias atuais. São Paulo: Editora Contexto, 2015.

GRAU, Eros Roberto. Por que tenho medo dos juízes (a interpretação/aplicação do direito e os princípios), ed. 6. São Paulo: Malheiros Editores LTDA, 2013.

HÄBERLE, Peter. A sociedade aberta dos intérpretes da Constituição: contribuição para a interpretação pluralista e "procedimental" da Constituição. Trad. Gilmar Ferreira Mendes. Porto Alegre: Sergio Antonio Fabris Editor, 1997. 
HESSE, Konrad. A força normativa da Constituição. trad. por Gilmar Ferreira Mendes. Porto Alegre: Sergio Antonio Fabris Editor, 1991.

ITAGIBA, Ivanir Nogueira. O Direito Eleitoral na atualidade. In: MEDEIROS, Renata Leite Motta Paes (Coord.). Estudos Eleitorais, v. 12, n. 2, p. 137-150 Mai/Ago, 2017.

JOBIM, Nelson et al. Legislação eleitoral no Brasil: do século XVI a nossos dias. Brasília: Senado Federal, Subsecretaria de Biblioteca, 1996.

LASSALLE, Ferdinand. 0 que é uma Constituição?.Trad. Walter Stönner. São Paulo: Edições e Publicações Brasil, 1933.

LIMA, Rodrigo Britto Pereira. Reforma política e criação do direito pelo Tribunal Superior Eleitoral. In: MACHADO, José Amilcar (Coord.). Jornada de Direito Eleitoral das Escolas de Magistratura Federal, v. 20. Brasília: Tribunal Regional Federal da 1a Região, ESMAF, p. 190201. jun. 2013.

MACEDO, Elaine Harzheim. A função normativa da Justiça Eleitoral brasileira no quadro da separação dos poderes. Revista do Instituto do Direito Brasileiro, p.13871-13884, 2013. Disponível em: <http:// cidp.pt/publicacoes/revistas/ridb/2013/12/2013_12_13871_13884. pdf> Acesso em: 25 set. 2018.

MACEDO, Elaine Harzheim; SOARES, Rafael Morgental. 0 poder normativo da Justiça Eleitoral e a separação dos poderes: um paradigma democrático. Direitos fundamentais e democracia II. Florianópolis: Conpedi, p. 265-293, 2014.

MARCHETTI, Vitor; CORTEZ, Rafael. A judicialização da competição política: o TSE e as coligações eleitorais. Opinião Pública, v. 15, n. 2, n. p, 2009. Disponível em: < http://www.scielo.br/scielo.php?pid=S0104$-62762009000200006 \&$ script=sci_arttext\&tlng=ES $>$. Acesso em: 25 out. 2018.

MARIA PORTO LIMA, Ś́dia. 0 ativismo judicial e o judiciário eleitoral: um estudo da atividade legislativa do Tribunal Superior Eleitoral. Recife: Universidade Federal de Pernambuco. 2011.

MATTOS, Paulo Todescan Lessa. O Novo Estado Regulador no Brasil: Eficiência e Legitimidade. São Paulo: Singular, 2006.

MENDES, Gilmar Ferreira et al. Curso de direito constitucional, v. 2. São Paulo: Saraiva, 2009. 
MICHELS, Vera Maria Nunes. Direito eleitoral: de acordo com a Constituição Federal, LC 64/90, Leis 9.096/95, 9.504/97, 11.300/06, EC 52/06 e Resoluções do TSE. Porto Alegre: Livraria do Advogado, 2006.

MONTESQUIEU, Charles de Secondat. Baron de. 0 espírito das leis. ed. 7. Trad. por Pedro Vieira Mota. São Paulo: Saraiva, 2000.

NETTO, Delfim. 0 oportunismo do Congresso. Carta Capital. [S. l]. 2017. Disponível em: <https://www.cartacapital.com.br/revista/961/o-oportunismo-do-congresso>. Acesso em 29 mai. 2018.

NEVES, Daniel Amorim Assumpção. Ações constitucionais. ed. 3. Salvador: Editora JusPodivm, 2017.

RAMOS, Elival Silva. Ativismo judicial: parâmetros dogmáticos. ed. 2. São Paulo: Saraiva, 2015.

REIS, Márlon et al. Processo Eleitoral e o novo CPC: aplicação imediata. ed. 2, rev. e atual. Salvador: Juspodivm, 2016.

RIBEIRO, Fávila. Pressupostos constitucionais do direito eleitoral: no caminho da sociedade participativa. Porto Alegre: Sergio Antonio Fabris Editor, 1990. p. 133.

ROSA, Antonio José Miguel Feu. Direito constitucional. São Paulo: Saraiva, 1998.

SANTOS, Boaventura de Souza. Para uma Revolução Democrática da Justiça. São Paulo: Cortez Editora, 2007.

SCHAPP, Jan. Problemas fundamentais da metodologia jurídica. Trad. por Ernildo Stein. Porto Alegre: Sergio Antonio Fabris Editor, 1985.

SOBRAL, Daniel Santos Rocha. A Justiça Eleitoral e a magistratura federal. In: MACHADO, José Amilcar (Coord.). Jornada de Direito Eleitoral das Escolas de Magistratura Federal, v. 20. Brasília: Tribunal Regional Federal da 1aㅡ Região, ESMAF, p. 73-88, jun. 2013.

SOUSA, Anne Calland Serra de. Fidelidade partidária sob a perspectiva do ativismo judicial nas decisões do Supremo Tribunal Federal. In: OLIVEIRA, Daniel Carvalho et al. Temas de Direito Eleitoral: coletâneas de artigos. Teresina: Editora Quimera, 2013.

STRECK, Lenio Luiz. Entre o ativismo e a judicialização da política: a difícil concretização do direito fundamental a uma decisão judicial constitucionalmente adequada. Espaço Jurídico Journal of Law [EJJL], v. 17, n. $3,2016$. 
TRIBUNAL SUPERIOR ELEITORAL. Código Eleitoral Anotado e Legislação Complementar. [S.l., S.n., S.d.]. Disponível em: <http://www.tse. jus.br/legislacao/codigo-eleitoral/codigo-eleitoral-1/codigo-eleitoral-lei-nb0-4.737-de-15-de-julho-de-1965\#5-tit3-cap4>. Acesso em: 02 set. 2018.

TSE indefere pedido de registro de candidatura de Lula à Presidência da República. Tribunal Superior Eleitoral, [S. 1.], 01 set. 2018. Disponível em: < http://www.tse.jus.br/imprensa/noticias-tse/2018/Setembro/ tse-indefere-pedido-de-registro-de-candidatura-de-lula-a-presidencia-da-republica>. Acesso em 05 nov. 2018.

VOTAÇÃO na república velha tinha fraude sofisticada. Estadão, São Paulo, n. p, 30 out. 2010. Disponível em: <https://brasil.estadao.com. $\mathrm{br} /$ noticias/geral,votacao-na-republica-velha-tinha-fraude-sofisticada-imp-,632063> Acesso em: 02 set. 2018.

WELSCH, Gisele Mazzoni. Legitimação democrática do poder judiciário no novo Código de Processo Civil. São Paulo: Editora Revista dos Tribunais, 2016.

ZILIO, Rodrigo López. Direito eleitoral. ed. 5. Porto Alegre: Verbo Jurídico, 2016.

. Limites e vedações da pré-campanha eleitoral conforme a Lei 13.165/15. Conjur, [S. l.], n.p, 2016. Disponível em: <https://www.conjur.com.br/2016-set-08/rodrigo-zilio-limites-vedacoes-pre-campanha-eleitoral>. Acesso em: 24 out. 2018. 